\title{
A REVISION OF THE GENUS ANGOPHORA (MYRTACEAE)
}

\author{
G. J. LEACH* \\ (Accepted for publication 22.3.1985)
}

\begin{abstract}
Leach, G. J. (Biology Department, University of Papua New Guinea, P.O. Box 320, University Post Office, Papua New Guinea) 1986. A revision of the genus Angophora (Myrtaceae). Telopea 2(6): 749-779 - Seven species of Angophora are recognized, two of which are subdivided into three subspecies each. New taxa described are $A$. costata subsp. euryphylla, A. costata subsp. leiocarpa, A. bakeri subsp. crassifolia and A. bakeri subsp. paludosa. Distribution maps and keys to the species and subspecies are provided.
\end{abstract}

\section{INTRODUCTION}

Angophora is a small genus of shrubby to large trees endemic to Australia. It is predominantly found in the eastern coastal areas of Queensland, New South Wales and Victoria, the centre of distribution appearing to be in the North and Central Coast subdivisions of New South Wales.

Two species ( $A$. floribunda and $A$. costata) are widely distributed with a number of disjunct populations; the latter species also shows detectable infraspecific variation. All remaining species are much more restricted in their distribution, with $A$. hispida in particular being narrowly endemic.

Interspecific hybridization is known to occur in a number of localities where two species overlap in their distribution. Thus, both hybridization and geographic variation are identified as important factors contributing to the poor delimitation of some species. The resolution of these species complexes was achieved by utilizing both morphological measurements and chemical characters. Detailed morphological measurements were made on the leaves and fruit cassules, and chemical characters were restricted to leaf phenolics and leaf volatile oils.

The collections of all major herbaria in Victoria, A.C.T., New South Wales and Q eensland have also been examined. The revision therefore represents the conclusions based on the integration of all information provided by each of these approaches. Details of the chemical and morphological analyses can be found in Leach (1980).

A key has been constructed, based largely on the vegetative morphological characters of dried material. The distribution maps show all specimens examined.

\footnotetext{
*Present address: Herbarium of the Northern Territory, Conservation Commission of the Northern Territory, P.O. Box 1046, Alice Springs, N.T, 5750.
} 


\section{GENERIC AND SPECIFIC RELATIONSHIPS}

It is generally accepted that Angophora is very closely related to Eucalyptus, and in particular to the subgenera Blakella and Corymbia of Pryor \& Johnson (1971). Johnson $(1972,1976)$ has summarized the wide range of characters that support this view. Pryor \& Johnson (1971) also propose that Blakella and Corymbia are more closely related to Angophora than to other subgenera of Eucalyptus and should therefore be of equal taxonomic rank. A recent detailed cladistic study has suggested that Blakella and Corymbia are in fact more closely related to other subgeneric groups of Eucalyptus than to Angophora (Ladiges \& Humphries 1983), although Johnson (1984) has criticized these findings based on the data sets used. Further work on these relationships has been completed by Johnson who maintains the close relationship between Angophora, Corymbia and Blakella (Johnson pers. comm.). Angophora is a well defined group regardless of whether it is recognized at the generic or subgeneric level and any future re-arrangement of Eucalyptus will not affect the findings of this study.

The species relationships within Angophora are not fully elucidated, but this study basically supports the subgeneric classification proposed by Pryor \& Johnson (1971). A. floribunda, A. subvelutina and A. bakeri form one very closely related group. A. melanoxylon is a difficult species to place, but on a number of characters does show some affinity to this group. Such an arrangement agrees with the Floribundinae of Pryor \& Johnson (1971). Phytochemically, however, A. melanoxylon is somewhat anomalous in the Floribundinae and its placement in this group should be regarded as tentative. The remaining three species are not so readily placed into a single coherent group and Pryor \& Johnson (1971) recognized this by placing each species into separate subseries. It is suggested, however, that there are some affinities between these species. $A$. costata and $A$. woodsiana in particular are believed to be more closely related than gross morphology would indicate. This suggestion is well supported by chemical evidence in that both species produce stilbenes and a high level of sesquiterpenes (Leach 1980). On these grounds $A$. melanoxylon might be more correctly placed with these species. Clearly further evidence is needed to clarify these relationships.

Geographic isolation is considered to be an important factor in speciation within Angophora. This is well illustrated by the divergence of $A$. costata subsp. costata and subsp. leiocarpa. However, in assessing the extent of isolation of taxa, past distributions must be taken into account and some species have clearly been more widely distributed in the past. Disjunctions within $A$. floribunda, $A$. costata subsp. costata and $A$. bakeri subsp. bakeri are indicative of former wide distributions and this is further substantiated by the discovery of what appear to be fossil Angophora (A: costata ?) fruits in South Australia (Lange 1978).

\section{EVALUATION OF CHARACTERS}

The following is a brief summary of the characters considered for this revision. Chromosomes (Smith-White 1942), pollen (Pike 1956) and wood anatomy (Ingle \& Dadswell 1953) have been examined in Angophora and it appears unlikely that these characters will yield any useful taxonomic information at the species level. 


\section{Stem}

The genus is characterized by a persistent, rough, fibrous bark, with the exception of a single species in which the bark regularly decorticates leaving a smooth 'gum' bark. The production of modified underground stems known as lignotubers has been reported for the genus (Fletcher \& Musson 1918) and in this study has been observed in all species grown in the glasshouse, viz. $A$. costata, A. floribunda, A. bakeri and A. melanoxylon.

\section{Pubescence}

The pubescence on shoots, leaves, parts of the inflorescence and fruits of Angophora consists of two types of 'hairs'. The two types are almost invariably found together, although the proportions may vary considerably. All species exhibit pubescence on some morphological feature or at some ontogenetic stage. The degree of pubescence is found to vary greatly, both within and between species.

The terminology followed here is that proposed by Johnson (1972). 'Hair', as used in the descriptions, refers to the shorter, white, uniseriate, several-celled hairs arising singly from the epidermis. Bristle-glands, usually interspersed with the hairs, are much longer, stouter and an orange to rusty brown colour. They are described by Carr et al. (1970) as glandular hairs. However, as argued by Johnson (1972), they do not produce external secretions and so should be differentiated from glandular hairs. The name proposed by him of 'bristleglands' is adopted here. Ladiges (1984) has recently examined in detail the structure of the emergences in Angophora and Eucalyptus and has confirmed that the 'bristle-glands' are emergent oil glands. The swollen base of the bristle often remains as a prominent raised area after the bristle has broken off. These raised areas, which have been called tubercles, have a distinct resinous appearance.

\section{Leaves}

The leaves are typically opposite. The general shape varies depending on whether juvenile-type foliage is retained at maturity. The juvenile-type leaves are sessile and cordate at the base, while the adult leaves are petiolate, lanceolate and falcate in shape. The lateral veins are characteristically parallel at $60-80^{\circ}$ to the mid-vein.

The heteroblastic nature of the foliage in some species of Angophora is a source of some taxonomic confusion. The developmental pattern exhibited within Angophora is very similar to that in Eucalyptus. While some seedling characteristics of Angophora have been reported (Hall 1912), the comparable developmental sequences in Eucalyptus have been discussed and described in much more detail (e.g. Penfold \& Willis 1961). The five different leaf types in Eucalyptus as recognized by Penfold \& Willis (1961) are found in Angophora.

Several species of Angophora retain the juvenile-type foliage throughout the life of the tree. These species are $A$. subvelutina, $A$. hispida and, to some extent, $A$. melanoxylon. As the juvenile foliage of $A$. floribunda and $A$. woodsiana is similar to the leaves of the mature plant of $A$. subvelutina, any growth from accessory or epicormic buds in the two former species will give the impression of intermediacy to $A$. subvelutina.

Whether those species that retain a juvenile-type foliage ever produce any petiolate, lanceolate leaves seems to vary between species. A. melanoxylon is one 
example where both types of leaves can occur normally on the one specimen. Within $A$. hispida all occurrences of petiolate leaves are attributed to hydridization. The situation within $A$. subvelutina is unclear. Thus it is important for taxonomic purposes to be able to distinguish between juvenile leaves and those produced by hydridization. The production of sessile, cordate leaves associated with an epicormic knob or the presence of particular scars (Jacobs 1955) is a clear indication that the leaves are juvenile rather than a product of hydridization. Long internodes are another common feature associated with juvenile leaves. In use of the keys and determination of specimens it is important that juvenile leaves are recognized.

\section{Inflorescence}

Briggs \& Johnson (1979) have given detailed descriptions of the inflorescence of Angophora. Further discussion on the inflorescence is also found in Leach (1980). The taxonomic value of the inflorescence at the species level is limited. For example, three of the four types of inflorescence described by Briggs \& Johnson (1979) in Angophora are found in one species.

\section{Flower}

The broad-based petals of Angophora have a two-part structure. On the outer surface of the almost circular petal is a raised triangular region, termed the keel, which is thicker and more rigid, commonly pubescent, and of a different colour from the distal portion of the petal. The keel is aristate. The distal, pale coloured, thinner portion of the petal is termed the limb. In the bud the keels are valvate, with the aristae forming a pointed region terminating the bud. The petal limbs are imbricate (see Fig.1).

\section{Phytochemistry}

There are isolated reports of different classes of plant products in Angophora and some of these reports are of a systematic nature (e.g. Smith 1913). However, none of these earlier publications produced significant results in terms of systematic work within the genus. In the present study, chemical characters proved to be extremely successful in elucidating several species complexes and several interesting patterns of variation were found. Details of the phytochemical work can be found in Leach (1980). Only the more outstanding features are briefly mentioned here.

In terms of the leaf phenolics the most outstanding feature is the production of stilbenes by some species. Stilbenes have been attributed systematic significance in various ways, but generally have not found wide application in plant systematics. Within Eucalyptus some workers have found the presence of stilbenes to be of systematic importance, while in other groups of Eucalyptus the taxonomic value of stilbenes has been limited due to the occurrence of chemical forms (Hillis 1967, Pederick \& Lennox 1979).

No evidence was found to suggest the presence of stilbene-producing chemical forms in Angophora. All collections made of $A$. costata, A. woodsiana, $A$. hispida and $A$. melanoxylon demonstrated the presence of stilbenes and these compounds were never detected in the remaining species. Stilbenes have therefore proved a useful taxonomic character in detecting hybridization and assessing species relationships.

The leaf volatile oils demonstrated a greater complexity in terms of overall patterns within the genus. The most distinctive pattern was the difference 
between some species in the proportion of $\alpha$-pinene and sesquiterpenes. All collections of $A$. floribunda and $A$. bakeri subsp. bakeri produced a volatile oil with high $\alpha$-pinene levels. The volatile oil of $A$. costata, $A$. woodsiana, $A$. hispida, A. bakeri subsp. crassifolia and A. bakeri subsp. paludosa contained high levels of sesquiterpenes. $A$. melanoxylon showed a variable pattern, but the sample size was too small to establish the basis of this variation. An interesting pattern of chemical forms was presented by A. subvelutina, with collections from the northernmost part of its range having high $\alpha$-pinene levels and the southern collections being high in sesquiterpenes.

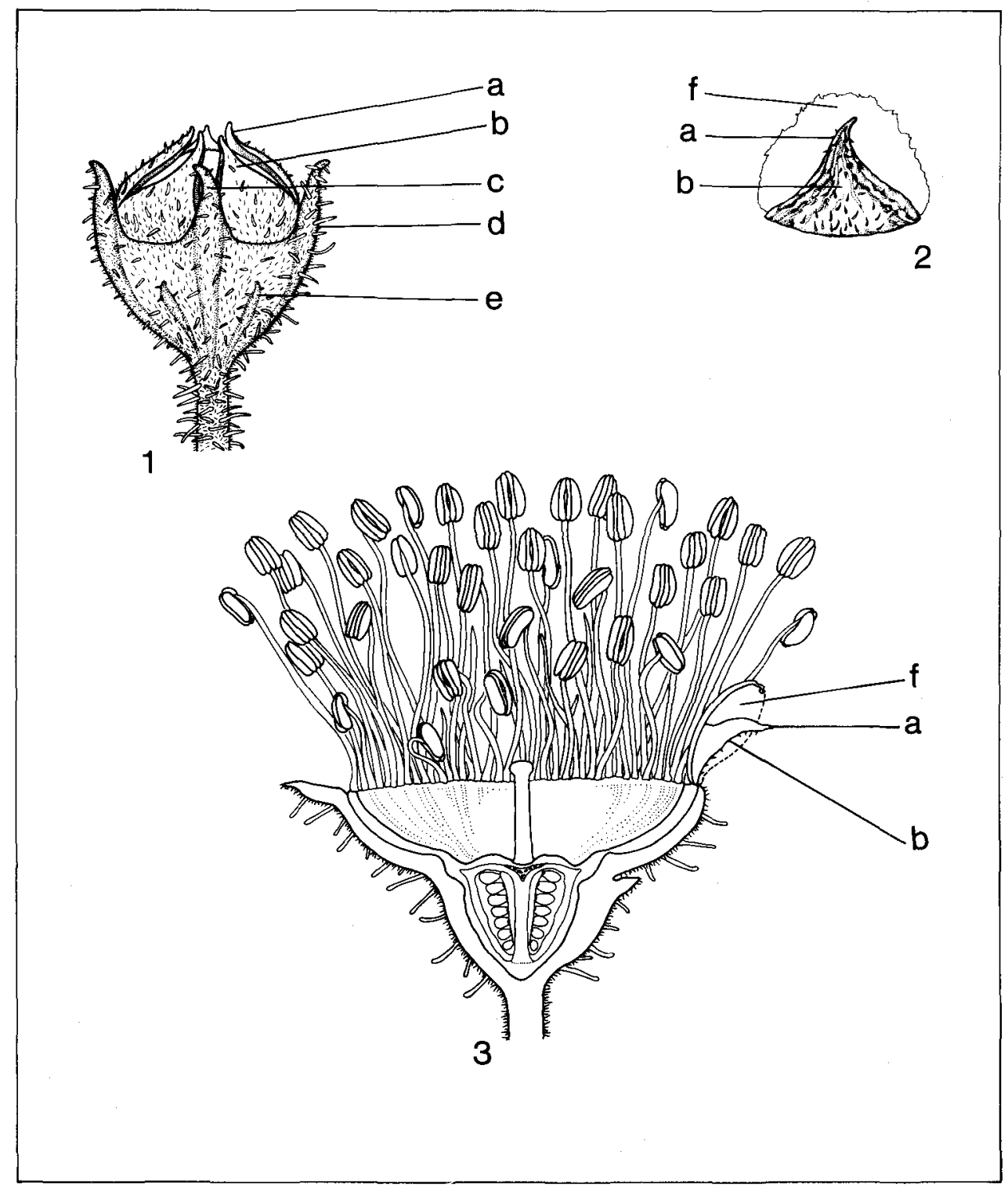

Fig. 1. Generalized floral structure of Angophora costata. 1. Flower bud (x 5). 2. Underside of petal (x 5). Half flower (x 5): a, arista; b, keel; c, sepal; d, primary or calycine rib; e, secondary rib; f, petal. 


\section{HYBRIDIZATION}

Hybridization has been recorded within the genus (Leach 1980, McGrath 1974) and has been observed in virtually all combinations that are geographically or ecologically conceivable. Two described species $(A$. clelandii and $A$. dichromophloia) are now generally accepted as having been described from hybrid material. The following species pairs have now been documented as hybridizing:

A. subvelutina $\times$ A. floribunda

A. bakeri subsp. bakeri $\times$ A. floribunda

A. woodsiana $\times$ A. subvelutina

A. woodsiana $\times A$. bakeri subsp. paludosa

$A$. costata subsp. costata $\times A$. hispida

A. bakeri subsp. bakeri $\times$ A. hispida

A. bakeri subsp. crassifolia $\times$ A. floribunda

A. costata subsp. leiocarpa $\times$ A. floribunda

In the first two combinations, hybridization is widespread and hybrid swarms may be produced. The Northern Tablelands in particular is an area where many hybrid populations between $A$. floribunda and $A$. subvelutina can be found. Angophora floribunda and $A$. bakeri subsp. bakeri hybridize extensively in the Hawkesbury River district and in this area one particular hybrid swarm studied showed three-way hybridization between these two species and $A$. subvelutina (Leach 1980). All other parental combinations as listed are known to produce only sporadic $\mathrm{F} 1$ individuals. Despite the wide occurrence of $A$. subvelutina $\times A$. floribunda hybrids, many supposed examples of hybridization may be attributed to a failure to recognize the juvenile leaves of A. floribunda.

The significance of hybridization in Angophora is difficult to assess. Clearly hybridization is responsible for much of the detected within-species variation. Its importance in terms of speciation is probably much less than that of geographic isolation.

\section{LIFE HISTORY}

Various aspects of the life history of Angophora have been examined by a few workers. Prakash (1969) provides very detailed observations on the stages of the life cycle from floral initiation to the mature seed and embryo. Floral development in Angophora has also been discussed by Pryor \& Knox (1971), who question some of the observations made by Prakash.

The work of Auld (1978) documents some interesting aspects of the life history of $A$. hispida. He found that this species was very dependent on fire for extensive regrowth and flowering. Other features documented by Auld that have some importance to considerations of gene flow in the genus were the low seeddispersal ability and the suggested extreme longevity of individuals. The findings of Auld's study are likely to be applicable to some other species in the genus $(A$. costata and $A$. bakeri) as these occur in the same fire-dominated habitat as $A$. hispida.

The flowers appear to be predominantly insect-pollinated, with bees, beetles, flies and ants all having been observed on the flowers seeking both the pollen and nectar that is produced (Prakash 1969, pers. obs.). Nectar-feeding 
parrots have also been observed feeding on the flowers and they could also be effective pollinators, but are thought to be quite secondary when compared with the various groups of insects.

\section{TAXONOMIC HISTORY}

The first species of Angophora described was A. costata. It was delineated by Joseph Gaertner in 1788 from material loaned to him by Sir Joseph Banks, and placed in the then broadly conceived genus Metrosideros. Two further species (hispida and floribunda) were described, also in Metrosideros, by Smith in 1797 from specimens sent to him by Surgeon General White from the settlement at Port Jackson. Later in that same year Cavanilles (1797), apparently unaware of Smith's publication, erected the genus Angophora based on Gaertner's description of $M$. costata and on $A$. cordifolia Cav., which later proved to be a synonym of $A$. hispida.

The generic delimitation by Cavanilles does not appear to have been readily accepted by some botanists of the day. Smith, in a second description of $A$. hispida (1805), maintained it as Metrosideros and was quite caustic in his comments about Cavanilles' new genus. Andrews (1803), Persoon (1806) and Ventenat (1803) all included various descriptions of, or references to, Angophora under Metrosideros. However, all authors subsequent to these have accepted Cavanilles' generic delimitation.

\section{Angophora Cav., Icon. 4: 21 (1797)}

Small shrubs to large trees, usually with crooked gnarled branches. Leaves opposite. Pubescence of white, straight hairs, up to $0.5 \mathrm{~mm}$ long, interspersed with longer, stout, orange to rusty brown bristle-glands, up to $6 \mathrm{~mm}$ long. Umbellasters of 3-7 flowers, or fewer by abortion, arranged in determinate or indeterminate thyrsoid or thyrsiform inflorescences; indeterminate growth rarely continued beyond flowering region. Peduncle flattened distally, terminating in a caducous involucre of small bracteoles. Flowers bisexual, pentamerous, rarely tetramerous, pedicellate. Hypanthium extending beyond inferior ovary, nectariferous disc lining inner wall of upper hypanthium above ovary, 4-5 prominent longitudinal ribs projecting above the rim as sepals, 4-5 intervening lesser secondary petaline ribs continuous with the aristae of the petal in the flower bud. Petals creamy white, imbricate in bud, circular, broadly attached at base, spreading, free, keeled and aristate on proximal half of undersurface, deciduous. Stamens numerous in several rows, free, versatile. Filaments creamy yellow, rarely pink, glabrous, narrowing abruptly into the connective that is terminated by a gland, inflexed or infolded in the flower bud. Anthers creamy yellow, bilobed, opening by two longitudinal slits. Ovary 3- or rarely 4-loculate. Style single, simple. Fruit a hard, woody capsule, enclosed by hypanthium, longitudinal ribs present, secondary ribs prominent, dehiscing by terminal valves that remain below the rim of the hypanthium. Ovules hemianatropous, only one per locule maturing to seed. Ovulodes numerous. Seeds broadly elliptic, flat, with crinkled papery texture when shed, dark brown.

TYPE: Angophora hispida (Sm.) Blaxell (A. cordifolia Cav.).

Two species, Metrosideros costata and Angophora cordifolia, were the basis of the new genus Angophora. Cavanilles did not indicate a type species; however, McVaugh (1956) selected A. hispida (syn. A. cordifolia) as the type species. 


\section{KEY TO SPECIES}

1a Bark decorticating in flakes leaving a smooth, orange to pink to pink-grey bark

1. A. costata

1b Bark rough, fibrous to sub-fibrous, persistent to smallest branches 2

2a Leaves all with attenuate or acute bases; petiolate 3

$2 \mathrm{~b}$ Some or all leaves with cordate to auriculate leaf bases; sessile or sub-sessile

3a Leaves thin, flexible; small to large trees 4

3 b Leaves thick, stiff, coriaceous; small shrubby trees 2. A. bakeri

4a Leaves $0.5-1 \mathrm{~cm}$ wide, rarely to $1.5 \mathrm{~cm}$; petioles $3-7 \mathrm{~mm}$ long, rarely to $10 \mathrm{~mm}$; leaf length: width ratio $>8$

2. A. bakeri

$4 \mathrm{~b}$ Leaves usually $>1.5 \mathrm{~cm}$ wide; petioles usually $>8 \mathrm{~mm}$ long; leaf length: width ratio usually $<5$

5a Capsules (10-)11-15 mm long, (9-)10-15(-16) $\mathrm{mm}$ wide; pedicels (10-)15-25(-30) $\mathrm{mm}$ long; petioles $(10-) 12-17(-20)$ $\mathrm{mm}$ long

3. A. woodsiana

5b Capsules 7-10(-12) $\mathrm{mm}$ long, $8-10(-12) \mathrm{mm}$ wide; pedicels (3-)4-8(-12) $\mathrm{mm}$ long; petioles $(6-) 8-12(-15) \mathrm{mm}$ long

4. A. floribunda

6 a Leaves $<2 \mathrm{~cm}$ wide, rarely as wide as $2.5 \mathrm{~cm}$ 5. A. melanoxylon

$6 \mathrm{~b}$ Leaves $>3 \mathrm{~cm}$ wide, rarely as narrow as $2 \mathrm{~cm}$ 7

$7 \mathrm{a}$ Leaves thick and rigid; capsules (15-)20-25 mm long,(13-) $15-20 \mathrm{~mm}$ wide; a small shrubby tree

6. A. hispida

$7 \mathrm{~b}$ Leaves thin, capsules 7-9(-11) $\mathrm{mm}$ long, 7.5-9(-11) $\mathrm{mm}$ wide; a medium-sized umbrageous tree 7. A. subvelutina

\section{A. costata (Gaertn.) Britten}

\section{Key to subspecies}

1a Capsules coarse (more or less thick-walled), strongly ribbed, usually $>12 \mathrm{~mm}$ diam., rarely as narrow as $9 \mathrm{~mm}$, sepals prominent, pedicels stout; leaves generally $>2 \mathrm{~cm}$ wide

1b Capsules thin-walled, $<12 \mathrm{~mm}$ diam., longitudinal ribs and sepals lacking or barely visible; leaves generally

$<2 \mathrm{~cm}$ wide 1c. subsp. leiocarpa

2a Capsules 9-15(-17) $\mathrm{mm}$ long, (9-)12-15(-17) $\mathrm{mm}$ wide; pedicels generally up to $8 \mathrm{~mm}$ long, very rarely to $12 \mathrm{~mm}$ 1a. subsp. costata

2b Capsules (14-)16-21 mm long, 14-20 mm wide; pedicels $8-15(-19) \mathrm{mm}$ long 1b. subsp. euryphylla

1a. Angophora costata (Gaertn.) Britten subsp. costata, J. Bot. 54: 62 (1916) Metrosideros costata Gaertn., Fruct. Sem. PI. 1: 171 (1788). Angophora lanceolata Cav., Icon. 4: 22, t.339 (1797) nom. illeg. (Illustrative specimen: Port Jackson in Nova Hollandia. MA, photo!). Metrosideros lanceolata (Cav.) Pers., Syn. Pl. 2: 25 (1806) nom. illeg. - 
Holotype: New Holland, Banks \& Solander S.n., 1770 (BM, photo!).

Metrosideros apocynifolia Salisb., Prodr. Stirp. 351 (1796) - TyPE:

'Sponte nascentem juxta Port Jackson legit Dav. Burton' (n.v.).

Angophora lanceolata var. hispida A. Cunn. ex A. Gray, U.S. Expl.

Exped., Phan. 1: 555 (1854) - HolotyPE: New South Wales, 'Wollongong and near Sydney' (GH, photo!).

Melaleuca costata Raeusch., Nomencl. Bot., ed. 3: 142 (1797) nom. nud., fide DC., Prodr. 3: 222 (1828).

Metrosideros splendens Gaertn. ex DC., Prodr. 3: 222 (1828) nom. nud.

Medium-sized to large tree to $30 \mathrm{~m}$ high, habit various, from a shorter gnarled tree with twisted branches to a straight-boled, erect tree, crown spreading. Bark orange to pink to pink-grey or becoming grey with age, smooth, deciduous, shed in large flakes, frequently stained orange with kino. Ultimate branchlets glabrous, reddish, often angular. Petioles (9-)14-22(-28) mm long, glabrous. Adult leaves narrow-elliptic to narrow-ovate, falcate, $(8-) 10-17(-19)$ $\mathrm{cm}$ long, (1.2-)2-3.5(-5) cm wide, 0.22-0.30(-0.35) mm thick, apex acute, base attenuate, margin entire, glabrous, shiny, dark green above, paler below, oil glands indistinct, side venation regular, parallel at $60-70^{\circ}$ to the midrib, lateral veins $1-1.5 \mathrm{~mm}$ apart, marginal vein $\mathrm{c}$. $1 \mathrm{~mm}$ from edge, veins more prominent below. Flower buds 3 per peduncle, rarely 7 . Peduncle $7-18 \mathrm{~mm}$ long, glabrous or densely covered with bristle-glands and short white hairs. Bracteoles elliptic, c. $4 \mathrm{~mm}$ long, c. $2 \mathrm{~mm}$ wide, pubescent as peduncle, glabrous forms tinged pin $\mathrm{k}$ at tips. Pedicel (2.5-)4-8(-12) $\mathrm{mm}$ long, stout, thick, flattened distally, pubescent as peduncle, principal ribs often continuing down pedicel. Hypanthium 5-7 mm long, 4-6 $\mathrm{mm}$ wide, pubescent as peduncle. Sepals to $3 \mathrm{~mm}$ long. Petals c. $4 \mathrm{~mm}$ long, 3-4 mm wide, limb glabrous, creamy white, keel glabrous or pubescent as hypanthium. Staminal filaments c. $7 \mathrm{~mm}$ long, creamy yellow, glandular area on connective present but obscure. Style c. $4 \mathrm{~mm}$ long. Capsule campanulate or narrowing at apex, 9-15(-17) mm long, (9-)12-15(-17) mm wide, straight or reflexed on pedicel, glabrous or slightly pubescent with both hairs and bristle-glands, smooth or roughened by the presence of tuberculate bristle bases; principal longitudinal ribs and sepals very prominent, secondary ribs also prominent, terminating $0-3 \mathrm{~mm}$ below rim; disc usually narrow, $1-1.5 \mathrm{~mm}$, descending, rarely level, sunken, commonly over-arched by capsule rim. Seeds $5.5-7.2 \mathrm{~mm}$ long, $4.3-6.2 \mathrm{~mm}$ wide. Cotyledons circular, (8-)10-14 mm long, 11-15(-19) mm wide, truncate or slightly cordate at base, glabrous, green above, either green or purple below, palmately veined, petiole 3-6 mm long. Juvenile leaves decussate, elliptic to ovate, to $12.5 \mathrm{~cm}$ long, $2.5-6.5 \mathrm{~cm}$ wide, apex acute, base auriculate, sessile, glabrous, oil glands indistinct, dark green above, paler below.

Distribution: Restricted to eastern New South Wales. Most common in the southern half of the North Coast subdivision, Central Coast and Central Tablelands (Fig. 2). There are also scattered populations in several areas of the South Coast. It is most commonly found on sandstone parent material, in dry, well drained sites.

Selected Specimens: New South Wales: North Coast: Port Stephens, Boorman NSW 143563, 8.1911 (NSW); near Coffs Harbour, Gauba s.n., 11.12.1956 (GAUBA 2644). Central Coast: New Holland, Banks \& Solander s.n., 1770 (MEL); Springwood, Boorman NSW 143506, 1.1913 (NSW); Outer Domain, Jones NSW 143531, 8.1889 (NSW). South Coast: Sugarloaf road near Wamban, Leach 433, 28.10.1976 (LTB). Central Tablelands: Mt Tomah, Maiden NSW 143565, 11.1898 (NSW). 


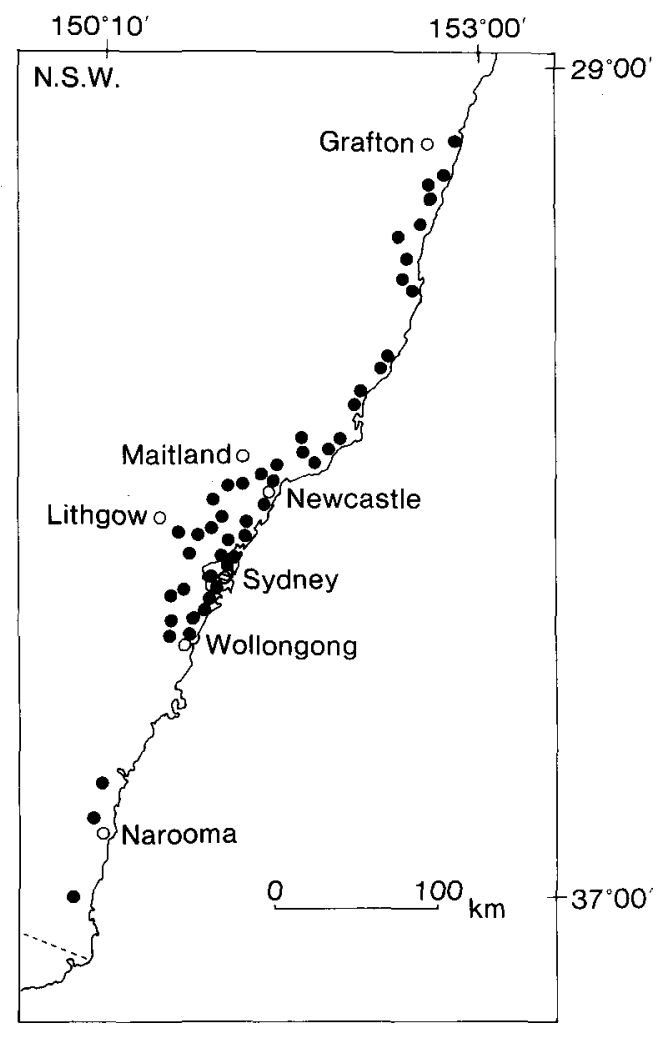

Fig. 2. Distribution of $A$. costata subsp. costata.

There are several nomenclatural problems with this taxon that remain to some degree unsolved. According to the records of Solander in the British Museum, 34 collections of $A$. costata were made by Banks \& Solander. Many of these collections are likely to have been referable to other genera and so the exact number of specimens examined by Gaertner is not known. There is a Banks \& Solander collection of $A$. costata at MEL that may represent part of the type material; however, this cannot be unequivocally established. Despite typification problems, the application of the epithet is clear from the protologue.

The type of Salisbury's Metrosideros apocynifolia could not be located to fully confirm the synonymy; $\mathrm{K}, \mathrm{BM}$ and $\mathrm{G}$ were checked as possible locations for this type. Britten (1916) claims Salisbury's description is cited by Cavanilles as a synonym of his $A$. lanceolata, but the name $M$. apocynifolia does not appear in the generic description of Angophora by Cavanilles (1797). The synonymy is also cited by Bentham (1867), but it is not clear how Bentham established it. The synonymy herein is based on Salisbury's description and the statements of Britten and Bentham.

The description and illustration of $A$. costata by Cavanilles (1797) erroneously attributes alternate leaves to this species. While the specimen seen by Cavanilles clearly has opposite leaves, the error in the description led Persoon (1806) to make the new combination Metrosideros lanceolata. 
De Candolle (1828) cites Metrosideros splendens Gaertn. as a synonym of A. costata. In Gaertner's publication (1788) there is no specific epithet 'splendens' associated with Metrosideros and it appears that de Candolle may have confused epithets and substituted 'splendens' for 'fulgens'. The type specimen of $M$. fulgens Gaertn. is a Banks \& Solander collection from New Zealand and is clearly not referable to Angophora.

The variety hispida published by Gray (1854) is described as being distinguished by the fine hoary pubescence and the reddish glandular bristles. Variation between hispid and non-hispid forms has been observed but does not appear to have any recognizable geographic or ecological association. The variety is clearly referable to $A$. costata subsp. costata. The varietal epithet hispida does not have priority for any of the subspecific categories recognized within $A$. costata in this revision.

$A$. costata subsp. costata is a distinctive taxon, but possible confusion can arise in the region of sympatry with subsp. euryphylla. Subsp. costata is known to hybridize very occasionally with the other two species of Angophora occurring on the sandstone in the Central Coast of New South Wales (A. hispida and $A$. bakeri). The hybrids are very distinctive on a number of morphological characters and unlikely to be confused with any other taxa.

The habit of subsp. costata can be extremely varied and is particularly dependent on habitat. On very exposed, dry sandstone outcrops it forms a very gnarled and often spectacular tree, whereas on better sites it will develop into a taller, more erect tree.

\section{1b. A. costata (Gaertn.) Britten subsp. euryphylla L. Johnson ex G. Leach subsp. nov.}

Arbor ad $25 \mathrm{~m}$ alta. Petiolus (10-)15-21 mm longus, folia adulta normalia (10-)14-18(-21) cm longa, (2-)2.5-4(-6) cm lata. Pedicellus crassus, 8-15(-19) $\mathrm{mm}$ longus. Capsula (14-)16-21 mm longa, 14-20 mm diam., paries crassus manifeste costatus. Folia latiora et capsulaes grandiores quam in subspecie typica.

HolotyPe: New South Wales: Central Coast: $3 \mathrm{~km}$ NW. of Gibbs Place, Putty, Pickard 1639, 26.4.1971 (NSW).

Medium-sized to large tree to $25 \mathrm{~m}$ high, commonly very gnarled with crooked branches. Petiole (10-)15-21 mm long. Adult leaves narrow-ovate, (10-)14-18(-21) cm long, (2-)2.5-4(-6) cm wide, $0.23-0.30 \mathrm{~mm}$ thick, lateral veins $1-3 \mathrm{~mm}$ apart. Peduncle $17-25 \mathrm{~mm}$ long, moderately to densely pubescent with both hairs and bristle-glands. Bracteoles elliptic, c. $10 \mathrm{~mm}$ long, 5-6 $\mathrm{mm}$ wide, moderately to densely pubescent as peduncle. Pedicel 8-15(-19) mm long, stout, thick, pubescent as peduncle. Hypanthium c. $8 \mathrm{~mm}$ long, $11 \mathrm{~mm}$ wide, pubescent as peduncle. Sepals up to $3 \mathrm{~mm}$ long. Petals $4-5 \mathrm{~mm}$ long, 5-6 mm wide, keel moderately to densely pubescent with both hairs and bristle-glands. Staminal filaments to $15 \mathrm{~mm}$ long, glandular area on connective brown and distinct. Capsule thick-walled, ovoid, (14-)16-21 mm long, 14-20 mm wide, moderately pubescent with both hairs and bristle-glands, roughened with tuberculate bristle-gland bases; principal longitudinal ribs and sepals very prominent, terminating $2-3 \mathrm{~mm}$ below rim; disc broad, 4-5 $\mathrm{mm}$, descending, usually sunken well below rim level. Seeds, cotyledons and seedling leaves not observed. 
DisTRIBUTION: Restricted to rocky sandstone outcrops in a small area of the Central Coast near Putty, Howes Valley and the Judge Dowling Range (Fig. 3).

Specimens Examined: New South Wales: Central Coast: Putty Road at Howes Mtn, Burgess s.n., 14.8.1970 (NE 035683, CBG 035397); Howes Mtn. Burgess s.n., 23.9.1960 (CBG 006964); Old Convict Road, $20.1 \mathrm{~km}$ E. of Howes Valley, Campbell 1199 \& Pickard, 26.7.1970 (NSW); 1 mile [1.6 km] N. of Gibbs Long Swamp, NNW. of Putty, Johnson NSW 127674, 14.11.1965 (NSW, FRI); Sampsons Pass, Judge Dowling Range, Johnson NSW 143610, 17.10.1965 (NSW); $1 \mathrm{~km} \mathrm{~N}$. of Putty on road to Windsor, Leach 225, 23.8.1975 (LTB).

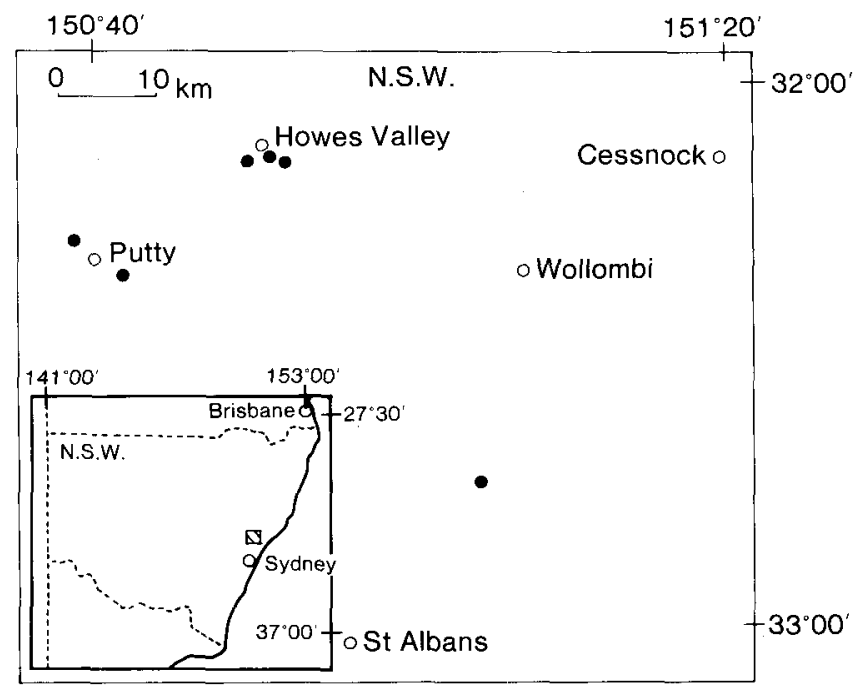

Fig. 3. Distribution of A. costata subsp. euryphylla.

For many years there has been informal recognition of this subspecies. It has been variously known as the 'Putty form' or the 'broad-leaved form'. Both the geographic and taxonomic limits of this taxon are not well known. A great need for further collection and observation exists, particularly relating to the extent of sympatry with subsp. costata. The new subspecies is best distinguished from the typical subspecies by the larger fruits and broader leaves. The subspecific epithet refers to the broad leaves [Greek: eurys = broad, phyllon = leaf].

1c. A. costata (Gaertn.) Britten subsp. leiocarpa L. Johnson ex G. Leach subsp. nov.

Arbor ad $25 \mathrm{~m}$ alta. Petiolus (8-)10-14(-18) $\mathrm{mm}$ longus, folia adulta normalia $6.5-12(-16) \mathrm{cm}$ longa, $(0.7-) 1-2(-3) \mathrm{cm}$ lata. Pedicellus gracilis, (4-)8-14(-18) mm longus. Capsula (8-)10-12(-14) mm longa, 7.5-10(-11.5) mm diam., paries tenuis, laevis vel costis inconspicuis in dentibus minutis decurrentibus.

Holotype: New South Wales: North Western Slopes: Just S. of Warialda, near High School, Leach 423, 25.8.1976 (LTB). Isotype: NSW.

Small to medium-sized tree to $25 \mathrm{~m}$ high, generally erect with slender bole. Petiole (8-)10-14(-18) $\mathrm{mm}$ long. Adult leaves narrow-elliptic to narrow-ovate, $6.5-12(-16) \mathrm{cm}$ long, $(0.7-) 1-2(-3) \mathrm{cm}$ wide, $(0.15-) 0.17-0.22(-0.26) \mathrm{mm}$ thick, lateral veins parallel at $70-80^{\circ}$ to midrib. Peduncle $15-32 \mathrm{~mm}$ long, glabrous. 
Bracteoles elliptic, 2-3 mm long, 1-2 mm wide, glabrous, rarely sparsely pubescent. Pedicel (4-)8-14(-18) mm long, generally filiform, glabrous, rarely sparsely pubescent. Hypanthium (2-)4-6(-8) $\mathrm{mm}$ long, 5-6(-8) $\mathrm{mm}$ wide, glabrous or rarely sparsely to moderately pubescent. Sepals absent or short, to $1 \mathrm{~mm}$ long. Petals c. $3 \mathrm{~mm}$ long, 3-4 mm wide, keel with bristle-glands. Staminal filaments c. $7 \mathrm{~mm}$ long, glandular area on connective brown, distinct. Capsule thin-walled, ovoid, rarely campanulate, usually narrowed at rim, (8-)10-12(-14) $\mathrm{mm}$ long, $7.5-10(-11.5) \mathrm{mm}$ wide, glabrous, young fruits occasionally glaucous, smooth; principal longitudinal ribs and sepals absent or barely visible; disc narrow, c. $1 \mathrm{~mm}$ wide, level or descending, sunken, obscured by over-arching rim. Seeds, cotyledons not observed. Juvenile leaves decussate, narrowelliptic to narrow-ovate, to $10 \mathrm{~cm}$ long, $0.6-1.5 \mathrm{~cm}$ wide, apex acute, base auriculate, sessile, glabrous or leaf bases on undersurface sparsely pubescent. Stem moderately to densely pubescent with hairs and bristle-glands.

Distribution: Widely distributed in the southeastern quarter of Queensland with scattered occurrences in the North Coast, Northern Tablelands, North Western Slopes and North Western Plains subdivisions of New South Wales (Fig. 4). It occurs on loose, well drained sandy soils on sandstone-capped hills or outcrops.

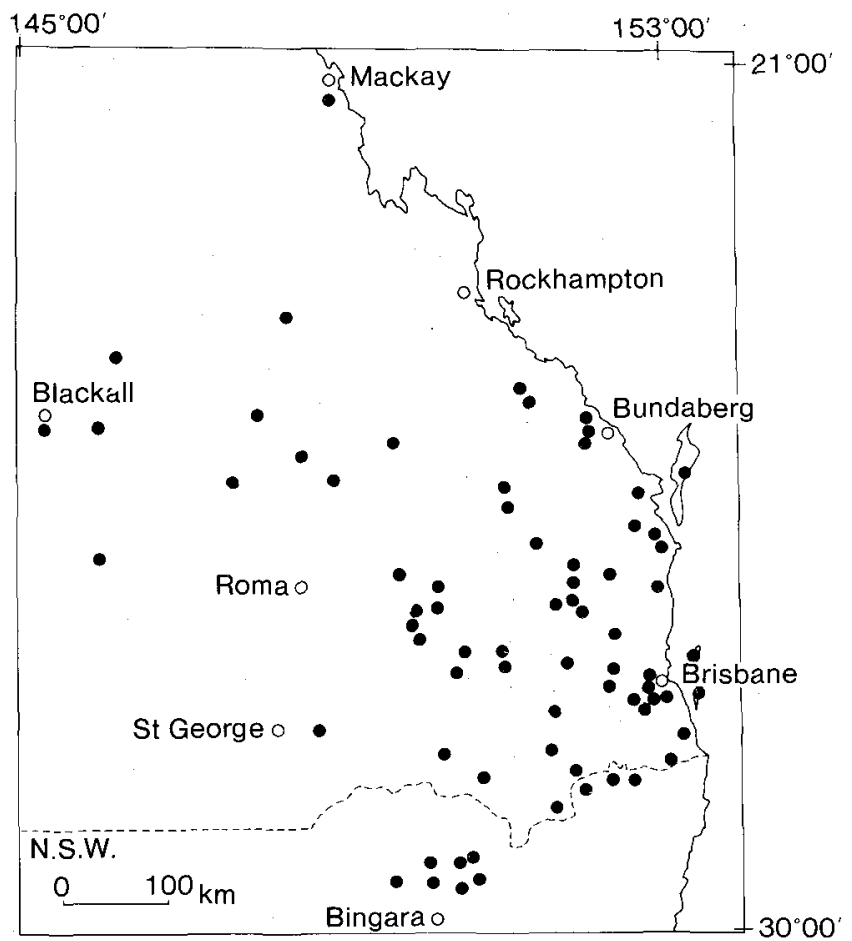

Fig. 4. Distribution of $A$. costata subsp. leiocarpa.

Selected Specimens: New South Wales: North Coast: Acacia Creek, Dunn 183, 19.9.1905 (NSW). Northern Tablelands: Maryland River Hwy, de Beuzeville s.n., 10.2.1941 (FRI 8164). North Western Slopes: Warialda, Leach 164, 27.5.1975 (LTB, NSW, BRI, CANB, CBG). North Western Plains: Yetman Road, de Beuzeville s.n., 11.2.1941 (FRI 8165). QueENSLAND: South Kennedy: Pioneer River, Griffiths s.n., 1889 (MEL). Mitchell: turnoff to Mt Moffat Station 
on road from Injune to Consuelo Tableland, Blaxell 1534, (LTB). Leichhardt: 32 miles [51.5 km] W. of Theodore Township, Lazarides 6927, 7.8.1963 (CANB 123604, BRI 051453, 051454, NSW). Port Curtis: Many Peaks road, 18 miles [30 km] W. of Bruce Hwy, Telford 777, 23.5.1969 (CBG 028727). Burnett: Eidsvold, Jones 2628, 26.2.1963 (CANB 210478); $2.2 \mathrm{~km}$ E. from Murgan, Leach 391, 21.8.1976 (LTB). Wide Bay: Goomeri to Ban-Ban road, Bisset S579, 29.10.1948 (CANB 17618, 269724); Fraser I., White 2512, 5. 1925 (BRI 230134). Warrego: 11 miles [17.7 km] N. of Charleville, Brooker 1486, 6.7.1968 (GAUBA 15021, 15020). Maranoa: Bunga Creek, Jensen s.n., (BRI 230123); 42 miles [67.6 km] E. of St George on Moonie Hwy, Phillips s.n., 17.9.1963 (CBG 028508, NE 023194). Darling Downs: 10 miles [16 km] E. of Condamine, Bateman s.n., 26.8.1962 (FRI 12086); 3 miles [4.8 km] NE. of Leyburn, Stauffer \& Everist 5527, 9.1.1964 (CANB 182051, MEL, BRI 111072, NSW). Moreton: Moreton I., c. $2 \mathrm{~km}$ N. of Tangalooma, Durrington \& Levine 1268, 10. 1973 (BRI 190604); 10 miles [16 km] S. of Ipswich, Melville 3653, 6.4.1953 (BRI 236044, MEL, NSW).

The northern distribution of a morphologically distinct subspecies within $A$. costata has long been recognized. C. T. White on many of his herbarium specimens annotated the northern material under $A$. 'queenslandica', but did not publish it. Pryor \& Johnson (1971) also recognize this taxon within their classification of the eucalypts.

It is a distinctive taxon showing no geographic overlap with either of the other two subspecies of $A$. costata. It is generally a more erect and slender tree than the other two subspecies and of a less hispid nature. No confirmed hybridization has been reported involving this taxon; however, two specimens (Webb \& Tracey, BRI 094819, 094820) are considered as possible hybrids between subsp. leiocarpa and $A$. floribunda.

The subspecific epithet refers to the smooth fruit [Greek: leios = smooth, karpon $=$ fruit], which distinguishes this taxon from the other smooth-barked subspecies of Angophora.

\section{A. bakeri C. Hall}

\section{Key to subspecies}

1a Leaves thin, flexible; capsules (5.5-)7-10.5 mm long; pedicels mostly $<10 \mathrm{~mm}$ long, rarely to $11 \mathrm{~mm}$ long

lb Leaves thick, stiff, coriaceous; capsules (9-)10-14 mm long; pedicels usually $>10 \mathrm{~mm}$ long 2c. subsp. crassifolia

2a Small tree usually $<10 \mathrm{~m}$ high; leaves rarely $>1 \mathrm{~cm}$ wide; in dry elevated sites 2a. subsp. bakeri

$2 \mathrm{~b}$ A generally taller tree up to $18 \mathrm{~m}$ high; leaves commonly $>$ $1 \mathrm{~cm}$ wide; in low-lying frequently inundated sites 2b. subsp. paludosa

2a. Angophora bakeri $C$. Hall subsp. bakeri J. \& Proc. Roy. Soc. N.S.W. 47: 103, t.iv (1913) - LectotyPe (here designated): "coastal district of New South Wales on Hawkesbury sandstone around Sydney' (n.v.) (the original plate).

Angophora lanceolata Cav. var. angustifolia A. Gray, U.S. Expl. Exped., Phan. 1: 556 (1854) - HolotyPe: New South Wales: 'Newington' (GH, photo!).

Angophora intermedia DC. var. angustifolia Cambage, Proc. Linn. Soc. N.S.W. 36: 548 (1911) nom. nud. 
Small tree $6-10 \mathrm{~m}$ high with slender often erect trunk. Bark grey, rough, soft, crumbly with short longitudinal fissures, persistent to smallest branchlets. Ultimate branchlets glabrous, angular. Petioles 3-7(-9) $\mathrm{mm}$ long, glabrous. Adult leaves narrow-elliptic, usually falcate, $(5-) 6-9.5(-13) \mathrm{cm}$ long, $0.5-1(-1.5)$ $\mathrm{cm}$ wide, $0.19-0.25 \mathrm{~mm}$ thick, apex acute, base attenuate, margin entire, glabrous or rarely very sparsely pubescent with fine white hairs on lower surface, shiny, dark green above, dull and paler below, oil glands numerous, large, distinct, venation fine, regular, parallel at $50-65^{\circ}$ to midrib, lateral veins c. $1 \mathrm{~mm}$ apart, anastomosing veins prominent, marginal vein c. $0.5 \mathrm{~mm}$ from edge, indistinct on upper surface. Flower buds 3 or 7 per peduncle. Peduncle $7-18 \mathrm{~mm}$ long, glabrous or sparsely pubescent with both hairs and bristle-glands. Bracteoles narrowly elliptic, $2-3 \mathrm{~mm}$ long, c. $1 \mathrm{~mm}$ wide, pubescent with bristle-glands. Pedicel 4-11 mm long, glabrous or sparsely pubescent. Hypanthium 4-5 mm long, c. $6 \mathrm{~mm}$ wide, glabrous or pubescent. Sepals $0.5-1 \mathrm{~mm}$ long. Petals $2.5-3 \mathrm{~mm}$ long, c. $3 \mathrm{~mm}$ wide, limb glabrous, creamy white, keel sparsely pubescent with both hairs and bristle-glands or becoming tuberculate with bristle-gland bases. Staminal filaments up to $5 \mathrm{~mm}$ long, creamy yellow, glandular region of connective brown, distinct. Style c. $3 \mathrm{~mm}$ long. Capsule ovoid or cylindrical, usually narrowed at rim, $8-10.5 \mathrm{~mm}$ long, $8-10(-12) \mathrm{mm}$ wide, usually reflexed on pedicel, glabrous or sparsely pubescent, smooth or roughened with tuberculate bristle-gland bases; principal longitudinal ribs just visible, secondary ribs less prominent or wanting, when present produced to rim; disc narrow, c. $1 \mathrm{~mm}$ wide, ascending or occasionally flat, just below rim, obscured by over-arching rim. Seeds, cotyledons not observed. Juvenile leaves decussate, narrow-elliptic to narrow-ovate, $4-7.5 \mathrm{~cm}$ long, $1.1-1.3 \mathrm{~cm}$ wide, apex acute, base auriculate with auricles often broader than lamina, sessile, glabrous.

Distribution: Restricted to the New South Wales coast and predominant in the Central Coast subdivision (Fig. 5). There are slight extensions north and west into the North Coast and Central Tablelands. A disjunct population also exists in the South Coast.

Selected Specimens: New South Wales: North Coast: 2 miles [3.2 km] W. of Karuah, Johnson NSW 143454, 12.10.1953 (NSW). Central Coast: Pennant Hills, Fraser NSW 143477, 12.1927 (NSW); S. of Bucketty on road to Singleton, Leach 449, 4.11.1976 (LTB, NSW, CANB). South Coast: c. 18 miles [28.8 km] E. of Tolwong, Campbell \& Pickard 1346, 27.12.1970 (NSW). Central Tablelands: bottom of Kedumba Pass, Jamieson Valley, Constable $N S W 48489,16.7 .1959$ (NSW).

The synonymy of $A$. lanceolata Cav. var. angustifolia A. Gray is established not only by examination of a photograph of the type but also on statements by Gray in the original description. The type specimen has no notes to indicate the bark type, which would have been decisive in establishing the synonymy. However, from the description, Gray obviously considers $A$. lanceolata $(A$. costata) to be quite polymorphous and to include $A$. intermedia ( $A$. floribunda), despite the difference in bark type. Thus, the rough-barked $A$. bakeri, which at the time was not distinguished from $A$. floribunda, has also been included under A. costata. The description by Gray of variety angustifolia does represent the first formal recognition of $A$. bakeri, but the epithet angustifolia does not have priority, having only been used at the varietal level.

There is an extreme dwarf form growing on barren exposed sandstone sites at Little Switzerland, Kings Tableland, and near Wentworth Falls in the Blue 


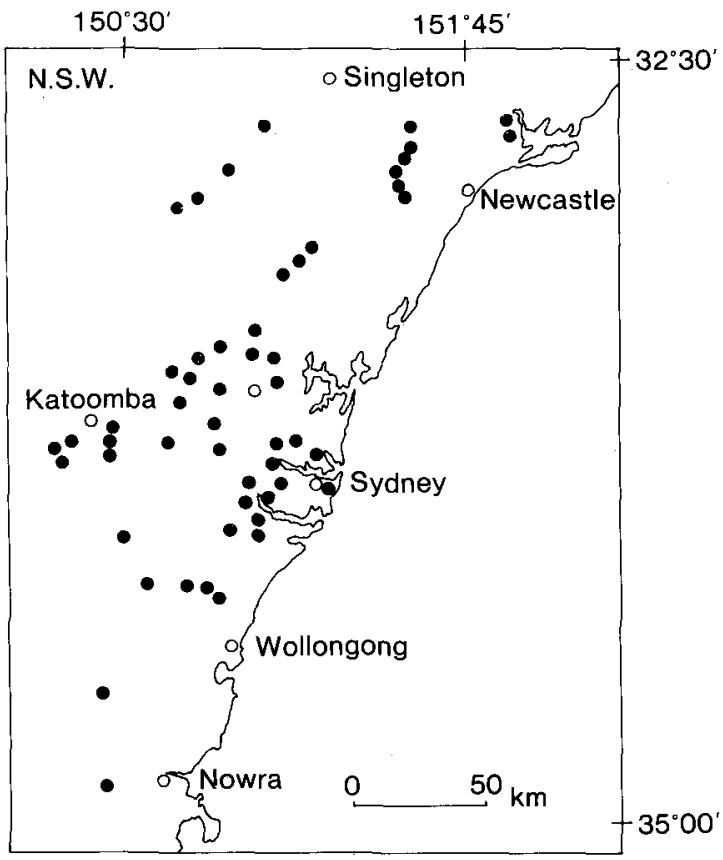

Fig. 5. Distribution of $A$. bakeri subsp. bakeri.

Mountains (Burgess s.n., CBG 007306). This form differs from the normal in that it is a shrub, c. $0.5 \mathrm{~m}$ high with petioles c. $2 \mathrm{~mm}$ long, leaves $2.5-4.5 \mathrm{~cm}$ long and 4-6 $\mathrm{mm}$ wide.

Several specimens (Garden NSW 143442, Johnson NSW 16381, Johnson \& Constable NSW 16426), which may be referable to $A$. bakeri, have been collected from the Central Western Slopes subdivision of New South Wales. If these specimens are indeed subsp. bakeri, then they represent a considerable westerly extension of the range. Their appropriate placement, however, remains uncertain, but may be resolved with further collections and/or phytochemical analysis. Until such information becomes available these specimens are best considered as $A$. floribunda.

Suspected clinal variation occurs in a north-south axis. The northerly collections, particularly those just extending into the North Coast, are generally broader in the leaves. While this may be attributed to introgression with $A$. floribunda, it has not been substantiated by chemical evidence.

2b. A. bakeri $C$. Hall subsp. paludosa $G$. Leach subsp. nov.

Arbor ad $18 \mathrm{~m}$ alta, gracilis, erecta. Folia adulta normalia $0.75-1.5(-2) \mathrm{cm}$ lata, vulgo lata quam typo.

Holotype: New South Wales: North Coast: $10 \mathrm{~km}$ south of Woodburn on Pacific Highway, Leach 195, 19 August 1975 (LTB). Isotype: NSW.

Small to medium-sized tree, slender, erect, to $18 \mathrm{~m}$ high. Petioles $4-8(-10)$ $\mathrm{mm}$ long. Adult leaves narrow-elliptic, $6.5-10(-12) \mathrm{cm}$ long, $0.75-1.5(-2) \mathrm{cm}$ wide, $0.18-0.24 \mathrm{~mm}$ thick, glabrous, oil glands small, indistinct, numerous, lateral veins more prominent below. Peduncle $8-20 \mathrm{~mm}$ long, moderately pubescent with short white hairs. Bracteoles obovate, $2.5-3 \mathrm{~mm}$ long, $1 \mathrm{~mm}$ or 
less wide, sparsely pubescent. Pedicel (3-)6-9 mm long, moderately to densely pubescent. Hypanthium $2.5-3 \mathrm{~mm}$ long, c. $4 \mathrm{~mm}$ wide, pubescent as peduncle. Petals 2-3 mm long, $2.5-3 \mathrm{~mm}$ wide, keel sparsely pubescent with white hairs. Staminal filaments 4-5 mm long. Capsule (5.5-)7-10 mm long, 7-11 mm wide, sparsely pubescent with white hairs, smooth or roughened with tuberculate bristle-gland bases; principal longitudinal ribs prominent, secondary ribs of equal prominence, disc narrow, c. $1 \mathrm{~mm}$ wide, flat or descending, just below rim or well sunken. Seeds, cotyledons and seedling leaves not observed.

DisTRIBUTION: Restricted to a small region of the North Coast of New South Wales between Grafton and Lismore (Fig. 6). Subsp. paludosa grows on alluvial soils of a loose sandy structure and occurs where waterlogging is common.

Selected Specimens: New South Wales: North Coast: Dilkoon-Gurranang, Johnson \& Constable NSW 143449, 6.6.1957 (NSW); at Iluka turn-off from Pacific Hwy, Leach 144, 24.5.1975 (LTB, NSW, CANB).

Distribution, habitat and morphology clearly distinguish this taxon from subsp. bakeri. Subsp. paludosa is frequently observed associated with the swamp-dwelling Melaleuca quinquenervia but on slightly drier sites to those occupied by $M$. quinquenervia. The habitat sets subsp. paludosa apart from the other subspecies of $A$. bakeri and from the remaining species in the genus. The subspecific epithet refers to the preferred low-lying, frequently swampy, habitats [Latin: paludosus $=$ swampy].

While there is an overall morphological similarity to subsp. bakeri, subsp. paludosa tends to be a taller, more slender tree with slightly broader leaves. Hybridization with $A$. woodsiana has certainly occurred, producing some broader leaved individuals, but hybridization does not seem to be widespread. It should be borne in mind that collections approaching the upper morphological limits of subsp. paludosa are likely to be the result of some introgression from $A$. woodsiana.

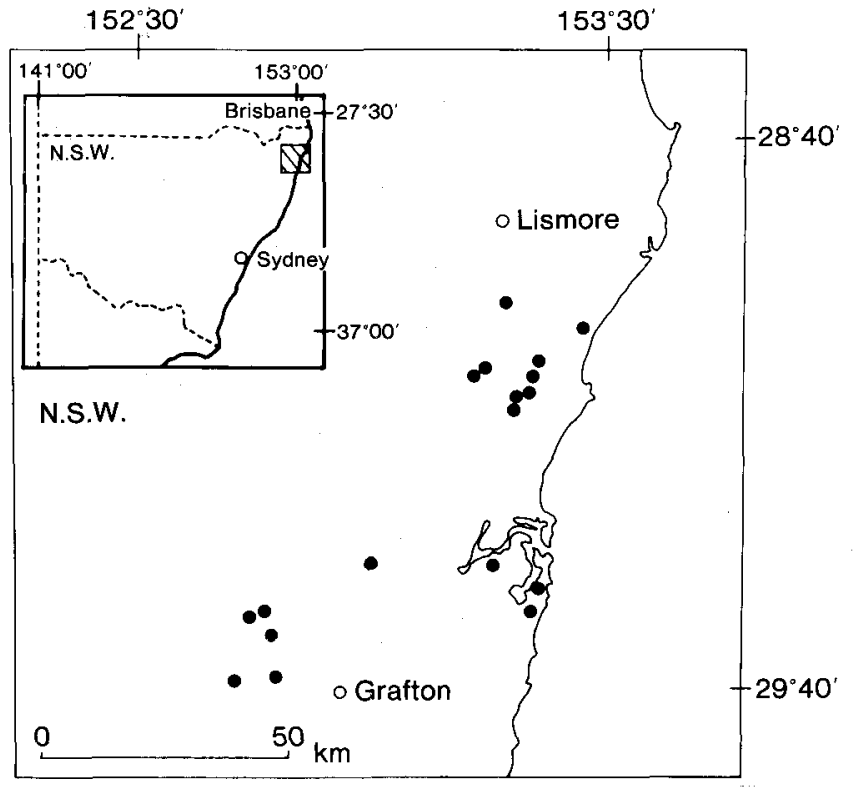

Fig. 6. Distribution of $A$. bakeri subsp. paludosa. 
2c. A. bakeri $C$. Hall subsp. crassifolia $G$. Leach subsp. nov.

Arbor fruticosa, 5-10 m alta. Folia adulta normalia rigida, coriacea, impolita, olivacea, nervis marginalis subtus valde elevatis.

Holotype: New South Wales: Central Coast: past St Ives towards Terrey Hills on the Mona Vale road, Leach 122, 21 May 1975 (LTB). Isotypes: NSW, CANB, BRI, MEL.

Small shrubby tree 5-10 m high. Petioles (5-)6-9(-11) $\mathrm{mm}$ long. Adult leaves narrow-elliptic to narrow-ovate, $(5-) 7.5-11 \mathrm{~cm}$ long, $(0.7-) 0.8-1.5(-2.0)$ $\mathrm{cm}$ wide, $0.30-0.44 \mathrm{~mm}$ thick, stiff, coriaceous, margin distinctly raised on lower surface, glabrous, dull, dark olive-green or grey-green above, paler below, oil glands indistinct, mid-vein and marginal vein prominent, yellow to brown, veins obscure on upper surface. Peduncle $15-25 \mathrm{~mm}$ long, moderately to densely pubescent with short white hairs interspersed with bristle-glands. Bracteoles elliptic, c. $3 \mathrm{~mm}$ long, $1-1.5 \mathrm{~mm}$ wide, pubescent as peduncle. Pedicel (8-) 10-14(-16) $\mathrm{mm}$ long, pubescent as peduncle. Hypanthium 4-5 mm long, 7-9 $\mathrm{mm}$ wide, pubescent as peduncle. Petals c. $3 \mathrm{~mm}$ long, c. $4 \mathrm{~mm}$ wide, keel pubescent with both hairs and bristle-glands. Staminal filaments up to $8 \mathrm{~mm}$ long. Capsule (9-)10-14 mm long, 9-12(-14) mm wide, sparsely to moderately pubescent, roughened with tuberculate bristle-gland bases; principal longitudinal ribs only just raised and visible, secondary ribs of equal prominence, disc narrow, c. 1-2 mm wide, flat, just below rim, obscured by over-arching rim. Seeds 6.3-6.9 mm long, 4.6-5.9 mm wide. Cotyledons circular, 9-12 mm long, 10-12 mm wide, slightly cordate at base, glabrous, dark green above, purple below, palmately veined, petiole c. 5-7 $\mathrm{mm}$ long. Juvenile leaves narrowelliptic, $6.5-8.5 \mathrm{~cm}$ long, $1.0-1.8 \mathrm{~cm}$ wide.

Distribution: An endemic of the Sydney region with the distribution centred on Middle Harbour and continuing north into Ku-ring-gai Chase National Park (Fig. 7). Occurring on sandstone parent material.

Selected Specimens: New South Wales: Central Coast: Tumbledown Dick, Blakely \& Boorman NSW 143467, 14.2 .1922 (NSW); 4.5 miles [7.2 km] E. of Gordon, Burgess s.n., 29.12.1965 (FRI, MEL, CBG 014038).

This taxon is most readily distinguished from the other two subspecies of $A$. bakeri and from $A$. floribunda by the thick, rigid, usually olive-green leaves. The distribution of $A$. bakeri subsp. crassifolia is not known to overlap with that of subsp. bakeri. There is a collection of subsp. crassifolia from Parramatta (Blakely \& Shiress NSW.118248, 7.1928; NSW, MEL). The known present distribution of subsp. crassifolia would suggest that this locality is incorrect.

The subspecific epithet (from the Latin crassus $=$ thick, folium = leaf) refers to the thick leaves that distinguish this taxon from other taxa in the Floribundinae.

3. Angophora woodsiana Bailey, Proc. Linn. Soc. N.S.W. 6: 143 (1882)

Angophora intermedia DC. var. woodsiana (Bailey) Bailey, Queensland Fl. 2: 605 (1900) - Holoty PE: Queensland: Eight Mile Plaïn, Bailey s.n. (BRI!).

Medium-sized to large tree to $20 \mathrm{~m}$ high. Bark grey to grey-brown, rough, fibrous or flaky, persistent to smallest branches. Ultimate branchlets glabrous, reddish, angular. Petioles (10-)12-17(-20) $\mathrm{mm}$ long, glabrous. Adult leaves narrow-ovate, often falcate, $(6-) 8.5-14(-17) \mathrm{cm}$ long, $(1.3-) 1.7-3.0(-4.5) \mathrm{cm}$ 


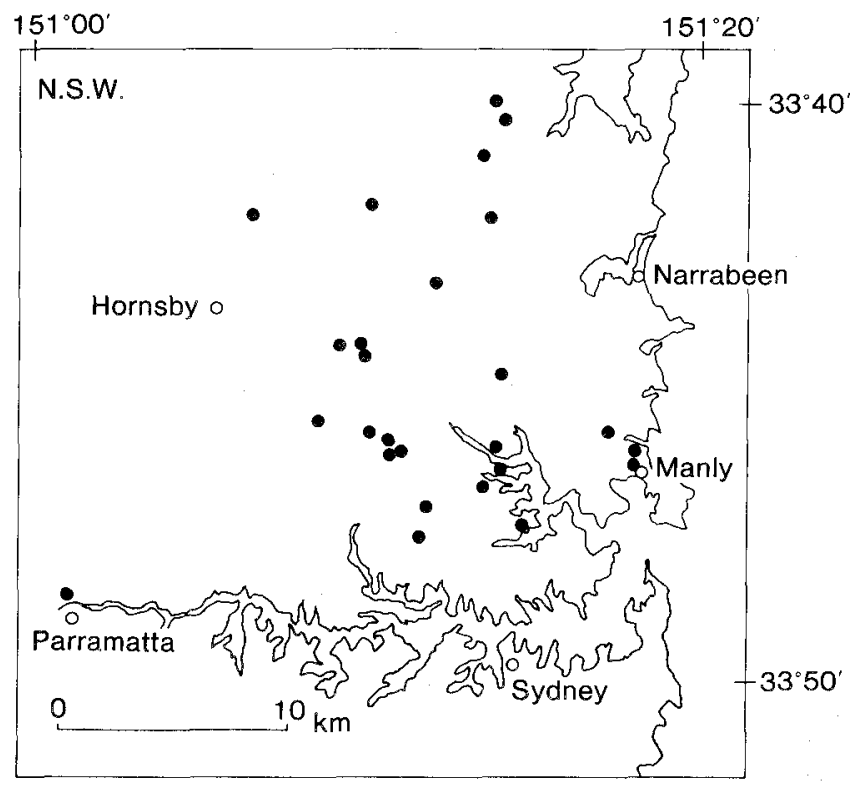

Fig. 7. Distribution of $A$. bakeri subsp. crassifolia.

wide, $0.17-0.31 \mathrm{~mm}$ thick, apex acute, base attenuate, margin entire, glabrous, green above, paler below, oil glands small, indistinct, venation regular, parallel at $60-80^{\circ}$ to midrib, lateral veins $1-1.5 \mathrm{~mm}$ apart, marginal vein $\mathrm{c}$. $1 \mathrm{~mm}$ from edge, veins more prominent below. Flower buds 3 or 7 per peduncle. Peduncle (9-)15-32 mm long, glabrous or moderately to densely pubescent with both hairs and bristle-glands. Bracteoles elliptic, c. $4 \mathrm{~mm}$ long, c. $2 \mathrm{~mm}$ wide, glabrous or pubescent as peduncle. Pedicel (10-)15-25(-30) $\mathrm{mm}$ long, sparsely pubescent as peduncle, usually sigmoid, filiform, narrowing towards peduncle, rarely thick and stout. Hypanthium 4-10 mm long, 5-10 mm wide, glabrous or pubescent as pedicel. Calyx teeth $3 \mathrm{~mm}$ long. Petals $3-4 \mathrm{~mm}$ long, c. $4 \mathrm{~mm}$ wide, limb glabrous or sparsely pubescent with white hairs, creamy white, keel glabrous or sparsely pubescent with bristle-glands. Staminal filaments to $7 \mathrm{~mm}$ long, creamy yellow, glandular area on connective brown and distinct. Style c. $3 \mathrm{~mm}$ long. Capsule ovoid or cylindrical, narrowed at rim, (10-)11-15 mm long, (9-)10-15(-16) mm wide, usually sharply reflexed on pedicel, glabrous or rarely slightly pubescent, usually smooth, rarely roughened by bristle-gland bases; longitudinal ribs and calyx teeth prominent, secondary ribs less prominent or absent, terminating $5-8 \mathrm{~mm}$ below rim; disc narrow, rarely to $2 \mathrm{~mm}$ wide, level, just below rim, commonly obscured by over-arching rim. Seeds, cotyledons, juvenile leaves not observed.

Distribution: Almost entirely restricted to the North Coast of New South Wales and the Moreton District of Queensland (Fig. 8). There are scattered occurrences outside these regions in the Darling Downs and Wide Bay Districts. It commonly occurs on sandstone hillsides or on deep gravelly or sandy soils.

Selected Specimens: New South Wales: North Coast: Coal Ridge, 10 miles [16 km] N. of Ramornie, Blakely \& Shiress NSW 143494, 7.1922 (NSW); N. of Red Rock, Johnson \& Watson 7530, 30.9.1972 (FRI, BRI 155199, NSW). QueEnSland: Wide Bay: Noosa River, White 1893, 21.3.1923 (NSW, BRI). 


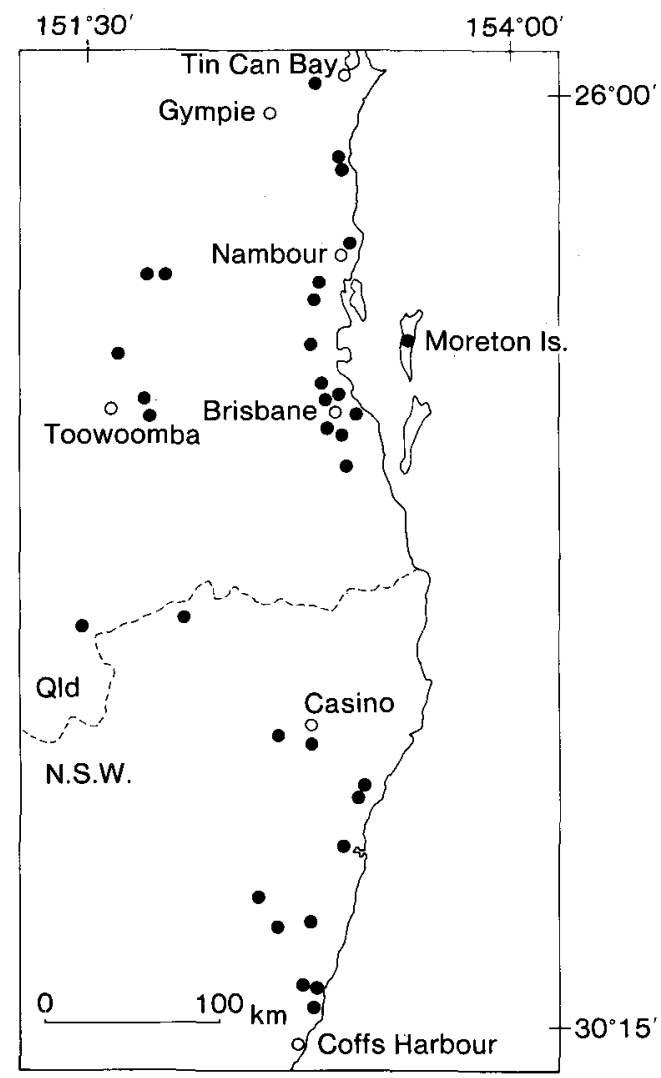

Fig. 8. Distribution of $A$. woodsiana.

Darling Downs: Silverwood, White 1738, 4.1922 (BRI 230112). Moreton: Burpengary, Bancroft NSW 143498, 6.1904 (NSW); N. of Helidon, Johnson \& Briggs 7074 A, 21.5.1971 (BRI 175124, FRI, NSW); Chermside, Melville \& Blake 3413, 22.3.1953 (MEL, BRI 236043).

A. woodsiana was described by F. M. Bailey in 1882; however, 18 years after describing the species he reduced it to a variety of $A$. floribunda (Bailey 1900). Domin (1928) was even more doubtful of the status of $A$. woodsiana and was of the opinion that it was not different from $A$. floribunda. Despite the reduction of the species by the original author, most taxonomists up to the present have accepted $A$. woodsiana in Bailey's original concept, that is, as distinct at the species level. In the most recent treatment of Angophora by Pryor \& Johnson (1971), it is placed in a monotypic series.

The slight overlap in morphological dimensions between these two species perhaps may suggest recognition at only the subspecific level. However, the concept of the species in this study is much broader than has previously been used. Chemical differences (Leach 1980) also support recognition at the specific level. While in the past there has been confusion in separating $A$. woodsiana and $A$. floribunda, they can for the most part be distinguished by capsule dimensions, although specimens of $A$. woodsiana with smaller fruits do approach the dimensions of $A$. floribunda. Fruits of $A$. woodsiana vary from a 
large, smooth form on an extremely slender pedicel to a particularly coarse, robust form with a stout pedicel found in the Toowoomba-Helidon region.

Hybridization with other species of Angophora appears to be very rare. No records exist of hybridization with $A$. costata subsp. leiocarpa. Only a few specimens are possible $A$. subvelutina $\times A$. woodsiana hybrids, which is to be expected from the different habitat preferences. The only evidence of possible extensive hybridization is with $A$. bakeri subsp. paludosa. As this is restricted by the small distribution of $A$. bakeri subsp. paludosa, it does not cause any significant problems in the recognition of $A$. woodsiana.

A. woodsiana typically occurs on sandstone or soils derived from sandstone parent material in dry, often elevated sites; however, it has also been recorded in wet situations on soils from alluvials to orange-red clays.

4. Angophora floribunda (Sm.) Sweet, Hort. Brit. ed. 2: 209 (1830)

Metrosideros floribunda Sm., Trans. Linn. Soc. London 3: 267 (1797) -

HolotYPE: Port Jackson, N.S.W., White s.n., 1795. (LINN, Herb. Smith No. 877.7, photo!).

Angophora intermedia DC., Prodr. 3: 222 (1828) - HolotYPE: New Holland, Lambert s.n., 1816 (G-DC, photo!)

See also A. ochrophylla R. T. Baker, p. 777.

Medium-sized to large tree, $15-30 \mathrm{~m}$ high, usually with gnarled and crooked branches and spreading crown. Bark brown to grey, rough, shortly fibrous, friable and generally furrowed, persistent to smallest branchlets. Ultimate branchlets glabrous, often red, angular. Petioles $(6-) 8-12(-15) \mathrm{mm}$ long, glabrous. Adult leaves narrow-elliptic to narrow-ovate, falcate, (5.5-)8-12(-15) cm long, (1.1-)2.0-3.0(- 5.0) $\mathrm{cm}$ wide, $0.16-0.26 \mathrm{~mm}$ thick, apex acute, base attenuate, margin entire, glabrous, dark green above, paler below, oil glands numerous and distinct, venation regular, parallel at $55-65^{\circ}$ to midrib, lateral veins $1-1.5 \mathrm{~mm}$ apart, marginal vein c. $0.5 \mathrm{~mm}$ from edge, veins more prominent below. Flower buds 3 or 7 per peduncle. Peduncle $15-30 \mathrm{~mm}$ long, glabrous or occasionally sparsely pubescent with short white hairs, bristleglands rare. Bracteoles elliptic, 3-4 mm long, c. $2 \mathrm{~mm}$ wide, glabrous to sparsely pubescent with white hairs, tuberculate. Pedicel (3-)4-8(-12) mm long, glabrous or moderately pubescent with hairs interspersed with bristle-glands. Hypanthium 4-6 $\mathrm{mm}$ long, 6-7 $\mathrm{mm}$ wide, glabrous, rarely pubescent as pedicel. Sepals $1-1.5 \mathrm{~mm}$ long. Petals $2-4 \mathrm{~mm}$ long, c. $3 \mathrm{~mm}$ wide, limb glabrous, creamy white, keel glabrous, roughly tuberculate. Staminal filaments $5-7 \mathrm{~mm}$ long, creamy yellow, glandular area on connective brown, distinct. Style c. $3 \mathrm{~mm}$ long. Capsule globular to ovoid, rarely cylindrical, often narrowed at rim, 7-10(-12) $\mathrm{mm}$ long, 8-10(-12) $\mathrm{mm}$ wide, straight or reflexed on pedicel, pubescent with both hairs and bristle-glands, tuberculate; principal longitudinal ribs prominent, secondary ribs also prominent, usually produced through to rim; disc narrow, $1-1.5 \mathrm{~mm}$ wide, level, just below rim level. Seeds 4.8-6.6 mm long, 3.2-5.3 mm wide. Cotyledons usually wider than long, rarely circular, (6-) $10-15 \mathrm{~mm}$ long, (8-)11-18 mm wide, base cordate, glabrous, dark green above, pinkish purple or green below, palmately veined, petiole $4-5 \mathrm{~mm}$ long. Juvenile leaves decussate, narrow-elliptic to narrow-ovate, to $9 \mathrm{~cm}$ long, $2-3.5 \mathrm{~cm}$ wide, apex acute, base auriculate, sessile, glabrous or sparsely pubescent towards leaf base.

Distribution: A species with a wide latitudinal distribution, and by following watercourses extends into the Western Plains of New South Wales 
(Fig. 9). At the northern and southern extremes of its main distribution it is very much restricted to the coast. It is absent from the northern part of the North Coast and all except the westerly and northern extremities of the Moreton District, Queensland. There is also one interesting disjunct population further north at Ravenshoe, near Atherton.

Selected Specimens: Victoria: Region Z: entrance of the Genoa River, Mueller s.n. (MEL); Mallacoota-Wingan coast, Beauglehole 32869, 27.12.1969 (MEL 524438). New South W-ALEs: North Coast: Tooloom Creek, Harbison NSW 143427, 10.1953 (NSW); Bulahdelah, Rupp NSW 143425, 12.1923 (NSW). Central Coast: 6 miles [9.6 km] NW. of Morisset, Story 6685, 30.9.1959 (CANB 72570, MEL, NSW). South Coast: Big Oakey, near Araluen, Phillips s.n., 22.4.1967 (CBG 019251). Northern Tablelands: $3.8 \mathrm{~km} \mathrm{SW}$. of Nundle, Chippendale 1235 \& Brennan, 10.4.1975 (FRI 025144, MEL, BRI 198551); between Tenterfield \& Legume, White 10309, 29.12.1935 (BRI 231100, 230230). Central Tablelands: c. $10 \mathrm{~km} \mathrm{~S}$. of Blackheath on road to Megalong Valley, Leach 461, 6.11.1976 (LTB, NSW). North Western Slopes: $1 \mathrm{~km} \mathrm{W.} \mathrm{of}$ Warialda, Leach 163, 27.5.1975 (LTB, NSW, BRI). Central Western Slopes: 2 miles [3.2 km] from Wollar on Ulan road, Story 6812, 10.10.1959 (CANB 72875, BRI 140444). North Western Plains: Narrabri, Deane s.n., 1889 (MEL). QueENSLAND: Cook: between Kaban \& Atherton, Roff s.n., 30.4.1954 (BRI 038789). North Kennedy: Tumoulin, Hyland 8258, 23.5.1975 (BRI 235294).

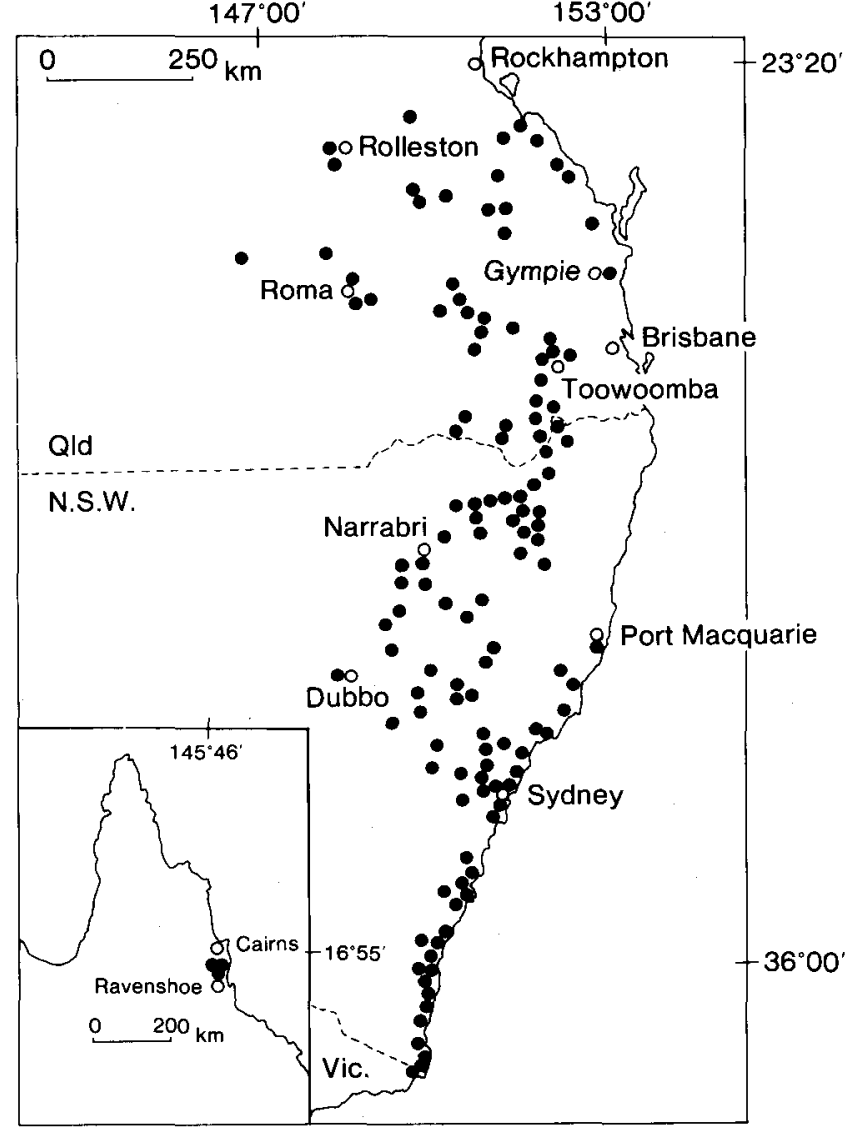

Fig. 9. Distribution of $A$. floribunda. 
Leichhardt: 3.6 miles [5.8 km] S. of Wandoan, Speck 193, 24.10.1963 (CANB 123748, MEL, BRI 197776, 197777, NSW). Port Curtis: 44 miles [70.4 km] from Bundaberg towards Rockhampton, Phillips s.n., 26.9.1969 (CBG 029974, BRI 098139). Burnett: c. 30 miles [48 km] W. of Mundubbera, Tothill N390, 9.8.1967 (BRI 082520). Wide Bay: Maryborough district, Young s.n., 9.1916 (BRI 2300881). Warrego: Chesterton, Blake 11110, 7.4.1936 (BRI 230103). Maranoa: Roma, Bick s.n., 7.1915 (BRI 230100, NSW). Darling Downs: Wyberba, Blake 4631, 23.1.1933 (BRI 133753, 133754). Moreton: $1 \mathrm{~km} \mathrm{~N}$. of Coolum Beach, Sharpe 1970, 24.1.1976 (BRI 204261).

A. floribunda is for the most part morphologically distinctive. Hybrids with A. subvelutina and $A$. bakeri subsp. bakeri occur where the taxa are sympatric.

Wide morphological variation is exhibited in A. floribunda, but it is not possible to attribute this to any geographical pattern. Characters that show greatest variation are leaf width, petiole length, fruit length and pedicel length.

5. Angophora melanoxylon $R$. T. Baker, Proc. Linn. Soc. N.S.W. 25: 84, t.ii (1900) - LectotYPE (here designated): Bäuerlen s.n., 2.1900 (NSW!)

Small to medium-sized tree to $15 \mathrm{~m}$ high, generally of a gnarled straggling habit, sometimes with two or more trunks, occasionally an erect tree. Bark dark grey, rough, shortly fibrous or sub-fibrous, friable, sometimes becoming furrowed, persistent to smallest branchlets. Ultimate branchlets pubescent with white hairs interspersed with bristle-glands. Petioles $1-3(-5) \mathrm{mm}$ long, glabrous to densely pubescent as stem. Adult leaves narrowly elliptic, (3-)4-6(-8) cm long, (0.6-)0.7-1.7(-2.5) cm wide, $0.17-0.32 \mathrm{~mm}$ thick, apex acute to rarely obtuse, base variable, both attenuate and cordate to auriculate leaves occurring in the same tree, lobes when present to $8 \mathrm{~mm}$ long, occasionally broader than the lamina, margin entire, sparsely pubescent on both surfaces with white hairs, very rarely with bristle-glands scattered over entire surface but concentrated towards leaf base, becoming glabrous with age, dull blue-grey or grey-green, \pm glaucous above, pale grey-green below, oil glands numerous but small and indistinct, venation regular, parallel at $60-65^{\circ}$ to midrib, lateral veins $1-1.5 \mathrm{~mm}$ apart, marginal vein c. $0.5 \mathrm{~mm}$ from edge, veins more prominent below. Flower buds 7 per peduncle, rarely 3 . Peduncle $6-23 \mathrm{~mm}$ long, moderately to densely pubescent as stem, becoming glabrous with age. Bracteoles narrowly elliptic, c. $3 \mathrm{~mm}$ long, $1 \mathrm{~mm}$ wide, pubescent with hairs. Pedicel 3-9 $\mathrm{mm}$ long, moderately to densely pubescent with predominantly bristle-glands. Hypanthium 4-5 mm long, 5-6 mm wide, pubescent as pedicel. Sepals to $2 \mathrm{~mm}$ long. Petals c. $4 \mathrm{~mm}$ long, 3-4 mm wide, limb glabrous, creamy white, keel pubescent with bristle-glands. Staminal filaments to $9 \mathrm{~mm}$ long, creamy yellow, glandular area on connective brown, distinct. Style c. $4 \mathrm{~mm}$ long. Capsule ovoid or cylindrical, usually narrowed at rim, $8-13 \mathrm{~mm}$ long, $7-11 \mathrm{~mm}$ wide, somewhat reflexed on pedicel, glabrous or rarely sparsely pubescent, often with a glaucous waxy bloom, smooth or roughened with tuberculate bristle-gland bases; principal longitudinal ribs and sepals prominent, secondary ribs less prominent, terminating 2-3 mm below rim; disc narrow, c. $1 \mathrm{~mm}$ wide, level or descending, sunken, often obscured by over-arching rim. Seeds $4-7 \mathrm{~mm}$ long, 3.5-5.5 mm wide. Cotyledons usually wider than long, rarely circular, $(6-) 9-12(-14) \mathrm{mm}$ long, (9-)11-14(-15) mm wide, apex obtuse, truncate to slightly cordate at base, glabrous, dark green above, pinkish purple below, palmately veined, petiole $\mathrm{c}$. $3 \mathrm{~mm}$ long. Juvenile leaves decussate, narrowly elliptic, $6.5-9 \mathrm{~cm}$ long, $1.6-2.7 \mathrm{~cm}$ wide, apex acute, base auriculate with auricles often broader than 
lamina, sessile, glabrous or with a few fine white hairs on midrib, oil glands prominent on lower surface, dark green above, paler below.

Distribution: North Western Plains of New South Wales and the Maranoa and Warrego Districts of Queensland (Fig. 10). Found particularly on deep sandy soil.

Selected Specimens: New South Wales: North Western Plains: Mulwarrina Creek, Mulgowan Station, Constable 4524, 15.10.1963 (BRI 096239, NSW); Gerara, c. 15 miles [24 km] E. of Enngonia, Moore 3567, 14.10.1964 (CANB 1502580, NSW). QueENSLAND: Maranoa: Bamble Station, 10 miles [16 km] N. of Mungindi, Cambage s.n., 21.9.1922 (BRI 230094, NSW). Warrego: S. of Charleville, Brooker 1403, 5.7.1968 (FRI).

Only two of the four probable syntypes have been found. A sheet (Coolabah, Peacock s.n., 5.1900, MEL 524439) predates publication but there is contradiction in the localities as the Peacock specimen in the description was cited as collected at West Bogan. A Bäuerlen collection at N.S.W. predates publication but has no locality details. This specimen would certainly have been seen by Baker and is therefore here selected as the lectotype.

A. melaxoxylon is a quite distinctive species with dark heartwood, a character found within the genus, only in this species. It has a somewhat patchy distribution but is often dominant. It is unusual with its mixture of auricled and non-auricled leaves, which may be found either consecutively along the stem or

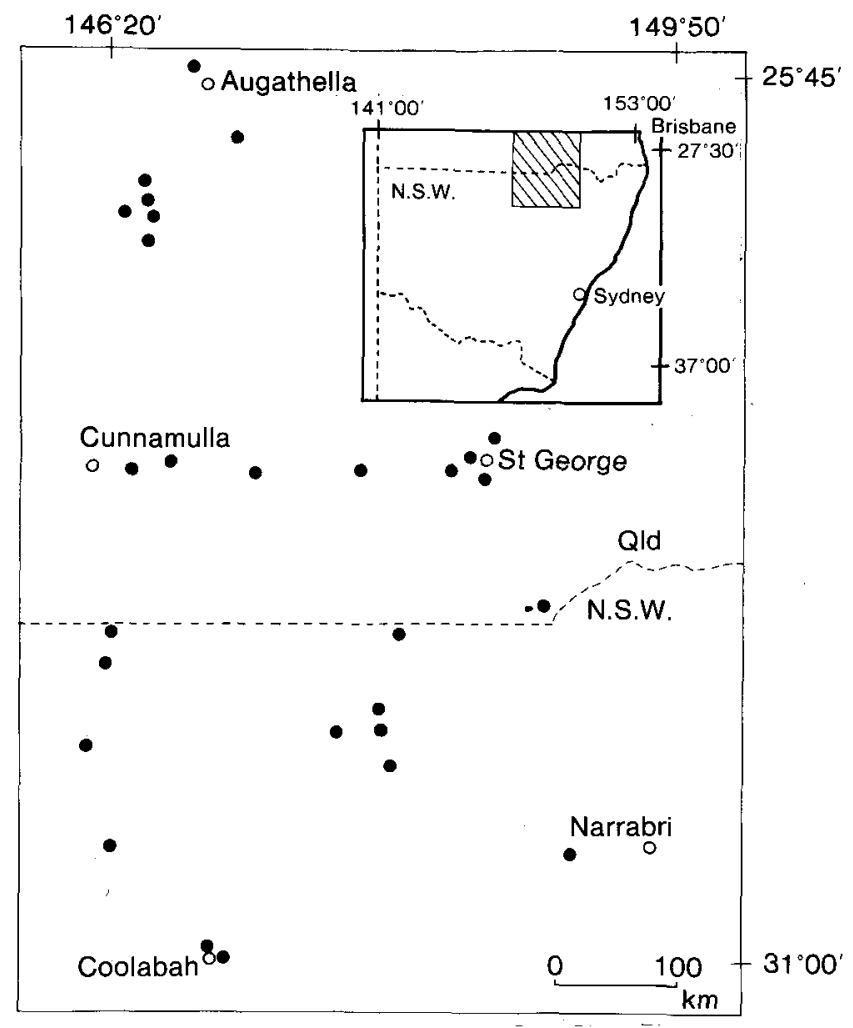

Fig. 10. Distribution of A. melanoxylon. 
in entire sprays of the one type. The auricled leaf base is the form predominant over most of the species range, but collections from the vicinity of Cunnamulla show forms with mostly attenuate leaf bases.

\section{Angophora hispida (Sm.) Blaxell, Kew Bull. 31: 272 (1976)}

Metrosideros hispida Sm., Trans. Linn. Soc. London 3: 267 (1797) HolotyPE: Port Jackson, White s.n., 1795 (LINN, Herb. Smith 877.9, photo!). Angophora cordifolia Cav., Icon. 4: 21, t. 338 (1797) - Metrosideros cordifolia (Cav.) Pers., Syn. Pl. 2: 25 (1806) - HolotyPe: Ex Port Jackson in Nova Hollandia (MA, photo!).

Metrosideros hirsuta Andr., Bot. Repos. 4, pl. 281 (I/III, 1803) LECTOTYPE (here designated): the original plate.

Metrosideros anomala Vent., Jard. Malm., pl. 5 (IV, 1803) - LECTOTYPE (here designated): the original plate.

Eucalyptus hirsuta Link, Enum. Hort. Berol. Alt. 2: 31 (1822) fide DC., Prodr. 3:222 (1828) - TYPE: at $\mathrm{B}^{\dagger}$ ?

Large bush to small shrubby tree, $1.5-8 \mathrm{~m}$ high, with typically gnarled and crooked branches. Bark grey to grey-brown, rough, fibrous or flaky, persistent to smallest branches. Ultimate branchlets densely pubescent with white straight hairs, thickly interspersed with bristle-glands. Petiole $0-4 \mathrm{~mm}$ long, usually densely pubescent as stem. Adult leaves elliptic to ovate, (4-)6-10(-11.5) cm long, (2-)3-4.5(-6) cm wide, $0.30-0.55 \mathrm{~mm}$ thick, rigid and leathery, apex obtuse, base auriculate, lobes to $8 \mathrm{~mm}$ long, sometimes broader than the lamina, margin slightly crenulate and undulate, glabrous to moderately pubescent with short white hairs over entire surface, bristle-glands restricted to midrib and major lateral veins, tending to become glabrous with age, surface either rough due to bristles or velvety if only hairs present, dull grey-green to olive-green above, dull grey-green below, oil glands indistinct, venation regular, parallel at $60-80^{\circ}$ to midrib, laterals (3-)5-8 $\mathrm{mm}$ apart, marginal vein c. $2 \mathrm{~mm}$ from edge, looping, veins raised and more prominent below. Flower buds 3 or 7 per peduncle. Peduncle $17-70 \mathrm{~mm}$ long, moderately to densely pubescent as stem. Bracteoles narrowly elliptic, 8-10 mm long, 1.5-4 mm wide, green or tinged with pink, occasionally persisting after anthesis, bristle-glands present. Pedicel (7-)15-20(-37) $\mathrm{mm}$ long, moderately to densely pubescent as stem with predominantly bristle-glands, often winged due to continuation of principal ribs. Hypanthium 7-10 $\mathrm{mm}$ long, $8-13 \mathrm{~mm}$ wide, densely pubescent as pedicel. Sepals 2-4 mm long. Petals 5-8 mm long, 7-10 mm wide, limb glabrous or sparsely pubescent with white hairs on lower surface, creamy white or rarely tinged with pink, keel pubescent with bristle-glands. Staminal filaments 8-12 mm long, creamy yellow or rarely pink in lower half, glandular area on connective not readily visible. Style $5-7 \mathrm{~mm}$ long. Capsule campanulate or narrowed at rim and urceolate, (15-)20-25 mm long, (13-)15-20 mm wide, straight or reflexed on pedicel, pubescent with bristle-glands, roughly tuberculate; principal longitudinal ribs and sepals prominent, secondary ribs also prominent, terminating $3 \mathrm{~mm}$ below rim; disc broad, c. $3 \mathrm{~mm}$ wide, level, at or just below rim. Seeds $7-10 \mathrm{~mm}$ long, $6.5-8.5 \mathrm{~mm}$ wide. Cotyledons elliptic, (12-)15-20 mm long, 11-18 mm wide, apex obtuse, base attenuate, glabrous, prominent raised oil glands on both surfaces, green above, green with pink tinge on lower surface, palmately veined, petiole $7-11 \mathrm{~mm}$ long. Juvenile leaves not observed.

Distribution: Confined to the Central Coast of New South Wales and almost invariably occurring on Hawkesbury Sandstone parent material (Fig. 11). 


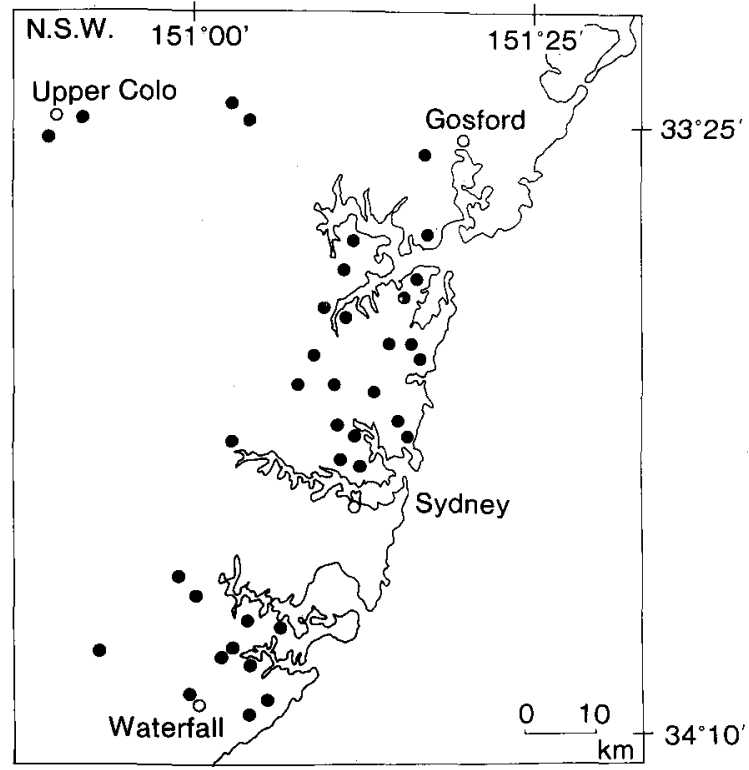

Fig. 11. Distribution of $A$. hispida.

A record for the Central Tablelands (Blue Mtns, Thorn s.n., 1884 (MEL)) is certainly a mistaken locality.

Selected Specimens: New South Wales: Central Coast: Terrey Hills, Burgess s.n., 27.12.1966 (CBG 016573); 2 miles [3.2 km] S. of Heathcote, Common s.n., 27.8.1968 (CANB 188867); road from Blaxlands Ridge to Upper Colo, Leach 134, 22.5.1975 (LTB, NSW).

There is no type specimen to confirm the synonymy of Eucalyptus hirsuta Link with $A$. hispida. However, de Candolle (1828) states that he saw Link's specimen and in fact makes particular reference to this specimen concerning the flower colour. The other collection seen by de Candolle (Sieber 471, 1828, G, photo!, MEL!) is clearly A. hispida. On this evidence, Eucalpyptus hirsuta is placed as a synonym of $A$. hispida.

$A$. hispida is a very distinctive species with a quite restricted distribution. Sporadic hybridization with both $A$. bakeri subsp. bakeri and $A$. costata subsp. costata has been detected (Leach 1980), and in the past hybrids have been described as new species. No significant introgression has been detected and the hybrids are sufficiently distinct as to cause little problem in identification. As with all other species of Angophora the flowers are a creamy yellow colour. However, one collection (Burgess CBG 016573) is a striking colour variant in which the basal half of the staminal filaments is a deep rosy pink. This form could have some horticultural value.

7. Angophora subvelutina $F$. Muell., Fragm. 1: 31 (1858) - LECTOTYPE (here designated): Burnett \& Brisbane river, 12.1856 (MEL!)

Medium-sized tree, commonly to $17 \mathrm{~m}$ high, occasionally to $25 \mathrm{~m}$, generally crooked with spreading crown. Bark grey, rough, flaky, usually lightly furrowed, persistent to smallest branchlets. Ultimate branchlets moderately pubescent with white hairs, sparsely to moderately interspersed with bristle-glands. Petioles 
0-1(-2) mm long, densely pubescent with white hairs. Adult leaves ovate to elliptic, (6-)8-9(-12) cm long, (2-)3-5(-7) cm wide, 0.15-0.24 mm thick, somewhat stiff, velvety, apex variable, acute to obtuse, base cordate to auriculate, lobes $4-7(-13) \mathrm{mm}$ long, margin entire to slightly crenate, sparsely pubescent with short white hairs on both surfaces, moderately pubescent towards leaf base, becoming glabrous with age, dull grey-green above, pale green below, oil glands indistinct, lateral veins regular, parallel at $60-70^{\circ}$ to midrib, 2-4 mm apart, marginal vein c. $1 \mathrm{~mm}$ from edge, looping, veins more prominent below. Flower buds 7 per peduncle. Peduncle $9-30 \mathrm{~mm}$ long, moderately pubescent with white hairs, sparsely to moderately pubescent with bristleglands. Bracteoles obovate, $3-4 \mathrm{~mm}$ long, c. $1.5 \mathrm{~mm}$ wide, densely pubescent on both surfaces with white hairs, rarely interspersed with bristle-glands. Pedicel (2-)3.5-10(-12) mm long, pubescent as peduncle. Hypanthium 4-6 mm long, 4-7 mm wide, pubescent as peduncle. Sepals c. $1 \mathrm{~mm}$ long. Petals 3-4 mm long, c. $3 \mathrm{~mm}$ wide, limb glabrous, creamy white, keel densely pubescent with white hairs. Staminal filaments up to $8 \mathrm{~mm}$ long, creamy yellow, glandular area on connective brown, distinct. Style c. 3-4 mm long. Capsule ovoid, commonly narrowed at rim, 7-9(-11) $\mathrm{mm}$ long, $7.5-9(-11) \mathrm{mm}$ wide, generally reflexed on pedicel, glabrous or moderately pubescent with short white hairs, smooth or tuberculate; principal longitudinal ribs prominent, secondary ribs often almost wanting, when present produced almost to rim; disc narrow, c. $1 \mathrm{~mm}$ wide, level, just below rim. Seeds, cotyledons and seedling juvenile leaves not observed.

Distribution: Mostly in the Central and North Coast of New South Wales and the Moreton, Wide Bay and Burnett Districts of Queensland (Fig. 12). As

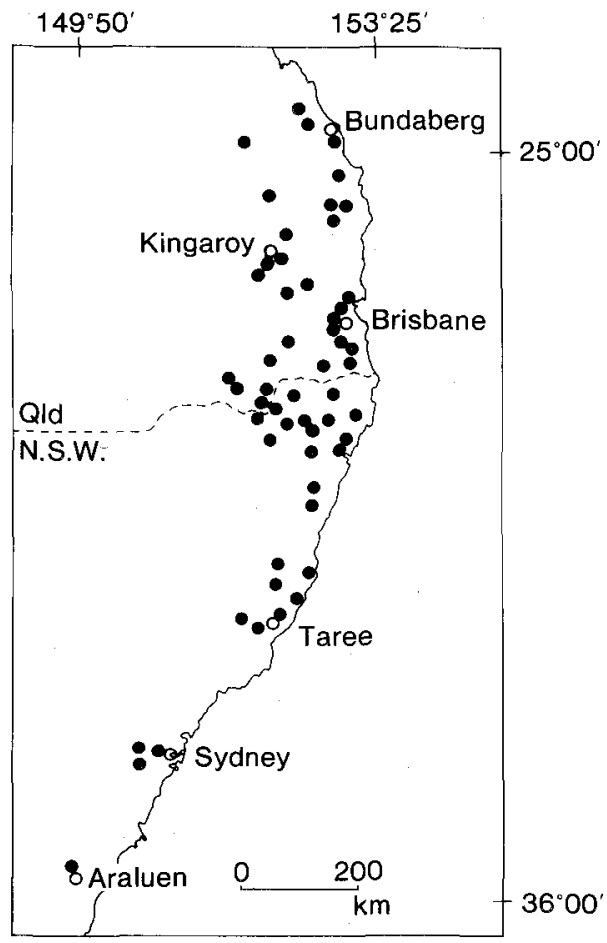

Fig. 12. Distribution of A. subvelutina. 
the species favours alluvial situations it is commonly associated with the major rivers, particularly of the North Coast in the Richmond, Clarence, Macleay, Hastings and Manning rivers. Further scattered occurrences are recorded in New South Wales from the South Coast, Northern Tablelands and North Western Slopes, and in Queensland from the Darling Downs, Port Curtis and North Kennedy Districts.

Selected Specimens: New South Wales: North Coast: Edinburgh Castle State Forest, Constable 6617, 1.12.1965 (BRI 134897, FRI); Casino roadside, Walker $A N U$ 1346, 2.1964 (GAUBA 396, 397, CANB 137418, 142923). Central Coast: Annandale, Camfield s.n., 12.1897, 12.1898 (BRI 230263). South Coast: Araluen Valley, $2 \mathrm{~km}$ NW. of Araluen on Majors Creek road, Briggs \& Johnson 4001, 11.12.1970 (NSW). Northern Tablelands: N. of Tenterfield, Gauba s.n., 12.12.1951 (CBG 002727). Central Tablelands: Mt Victoria, s.n., 2.1901 (MEL). Queensland: North Kennedy: Rockingham Bay, s.n., (MEL). Port Curtis: 57 km from Miriam Vale on road to Bundaberg, Leach 376, 19.8.1976 (LTB). Burnett: $71.5 \mathrm{~km} \mathrm{~N}$. of Mundubbera on Burnett Hwy, Leach 388, 20.8.1976 (LTB). Wide Bay: Kolan River, 30 miles [48 km] N. of Gin Gin, Banks B68, 3.7.1966 (FRI 14159). Darling Downs: The Ranch, Inglewood, Smith s.n., 21.5.1965 (BRI 063524, CANB 188657). Moreton: Petrie, Blake 2137, 21.1.1931 (BRI 230215).

The localities, Brisbane, Burnett and Boyd river, are given in the protologue. Only one of these collections is dated and as this predates publication, it is here chosen as the lectotype. The remaining syntypes are: Boyd river, s.n., MEL; Burnett, Brisbane, and Boyd river, s.n., MEL.

There is confusion over the locality given as Boyd River. It is suspected that this is a mis-spelling of Boyne River as no Boyd River is known to exist in Queensland. Leichhardt (1847) names the Boyd River and gives his expedition's latitude on the entry for the previous day as $25^{\circ} 19^{\prime} 19^{\prime \prime}$. This locality would be in the area of what is known today as the Boyne River and would exclude the Boyd River further south near Grafton in New South Wales. The Boyne river is within the range of $A$. subvelutina.

The occurrence of $A$. subvelutina from Rockingham Bay (based on a single collection at MEL) in the North Kennedy District of Queensland needs confirmation. This is a considerable distance north from the main distribution of $A$. subvelutina but with an equivalent disjunction within $A$. floribunda at Atherton it must be considered possible for this locality to be correct. Further scattered populations to the west and south of the main distribution may indicate a formerly more widespread occurrence of this species. In recent times $A$. subvelutina has certainly been much reduced due to clearing of the very productive alluvial plains on which it predominantly occurs. Sites such as at Rockingham Bay may well be completely cleared of original vegetation. However, the lack of further collections does suggest the locality on the specimen is incorrect.

This species is generally quite distinctive but hybridization and introgression in certain areas can cause problems with identification. Hybrids with $A$. woodsiana are rare and easily detected. Hybridization and probable introgression with $A$. floribunda is widespread and most apparent in the Sydney region and the North Western Slopes of New South Wales. Collections, particularly from these areas, showing intermediacy are best regarded as a result of hybridization between $A$. floribunda and $A$. subvelutina. 


\section{DOUBTFUL AND EXCLUDED SPECIES}

A. clelandii Maiden, J. \& Proc. Roy. Soc. N.S.W. 54: 175-176 (1920) -LECTOTYPE (here designated): Kogarah, Camfield NSW 143570, 9.12.1847 (NSW!).

The type material is from a hybrid between $A$. hispida and A. bakeri subsp. bakeri (based on the intermediate morphology and the distribution of the parental species). Three collections were cited in the type description by Maiden of which two have been located. The collection by Cleland comprises seven sheets but it is not certain that they represent duplicates, hence the Camfield specimen is chosen as the lectotype and the remainder are paratypes. From the known distributions of subsp. bakeri and subsp. crassifolia the paratypes would in fact be the result of hybridization between $A$. hispida and $A$. bakeri subsp. crassifolia.

A. dichromophloia Blakely, Contr. N.S.W. Natl. Herb. 1: 34 (1939) HoLOTYPE: Junction Road, Hornsby, Blakely s.n., 11.11.1928 (BRI!).

Described from material now recognized to be a result of hybridization between $A$. costata subsp. costata and $A$. hispida. Blakely made a number of collections from the type locality over a period of several years; however, only one sheet has been found that corresponds in all respects to the holotype designated by Blakely.

A. ochrophylla $R$. T. Baker, Proc. Linn. Soc. N.S.W. 38: 601 (1913)LестотYPE (here designated): Myall Creek nr. Bingara, Laseron NSW 167269, 4.1911 (NSW, n.v.).

In the type description there are two specimens cited from widely separated localities, viz. Myall Creek and Woodburn. It is considered likely that the material cited in the original description will be referable to both $A$. floribunda and $A$. bakeri subsp. paludosa. This conclusion is based on the geographic areas concerned and dimensions given in the type description. The "pale yellowish or ochreous leaves' noted by Baker may well have been due to waterlogging causing chlorosis in the leaves. Such a condition has been commonly observed in $A$. bakeri subsp. paludosa. Material examined by Baker would have been at the Museum of Applied Arts and Sciences, Sydney, but subsequently transferred to NSW. There are a number of sheets at NSW collected at Myall Creek that would have been seen by Baker. Apart from one mixed collection containing $A$. costata subsp. leiocarpa and $A$. floribunda, the material is all referable to $A$. floribunda. The protologue refers to rough bark so the chosen lectotype was a fruiting specimen of $A$. floribunda.

\section{ACKNOWLEDGMENTS}

I am indebted to Dr T. P. Whiffin and Dr R. J. Anderson for their invaluable support and advice throughout this study. Dr L. A. S. Johnson's comments on the manuscript are gratefully acknowledged. I am also grateful to the Directors of the following herbaria for loans and/or photographs of specimens: B, BM, BRI, CANB, CBG, FRI, G, GAUBA, GH, K, LINN, MA, MEL, NE, NSW, TUB. 


\section{REFERENCES}

Andrews, H. C. (1803). 'The Botanists Repository' (London) vol. 4: t. 281.

Auld, T. (1978). 'Survival and Reproduction in Angophora hispida (Sm.) Blaxell on the Hawkesbury Sandstone'. Honours thesis. University of Sydney, Sydney.

Bailey, F. M. (1882). On the flora of Stradbroke Island with a description of new species. Proc. Linn. Soc. New South Wales. 25: 84-86.

Bailey, F. M. (1900). 'The Queensland Flora' (Queensland Government: Brisbane) vol. 2, pp. 604-606.

Bentham, G. (1867). 'Flora Australiensis' (Lovell Reeve: London) vol. 3, pp.183-184.

Briggs, B. G. \& Johnson, L. A. S. (1979). Evolution in the Myrtaceae evidence from inflorescence structure. Proc. Linn. Soc. New South Wales 102: 157-256.

Britten, J. (1916). The plants of Salisbury's Prodromus. J. Bot. 54: 57-65.

Candolle, A. P. de (1828). 'Prodromus Systematis Naturalis Regni Vegetabilis' (Treuttel \& Würtz: Paris) vol. 3, p. 222.

Carr, S. G. M., Carr, D. J. \& Milkovits, L. (1970). Oil glands and ducts in Eucalyptus L'Hérit. III. The flowers of Series Corymbosae (Benth.) Maiden. Austral. J. Bot. 18: 313-333.

Cavanilles, A. J. (1797). 'Icones et Descriptiones Plantarum' (Typographia Regia: Madrid) vol. 4, pp. 21-22, t. 339.

Domin, K. (1928). Beiträge zur Flora and Pflanzengeographie Australiens. Biblioth. Bot. 22(895):1012-1014.

Fletcher, J. J. \& Musson, C. T. (1918). On certain shoot-bearing tumors of eucalypts and angophoras, and their modifying influence on the growth-habit of the plants. Proc. Linn. Soc. New South Wales 43: 191-233.

Gaertner, J. (1788). 'De Fructibus et Seminibus Plantarum' (Stuttgart) vol. 1, pp. $171-172$, t. 34 .

Gray, A. (1854). 'United States Exploring Expedition. Botany. Phanerogamia' (Philadelphia) Part 1, pp. 555-556.

Hall, C. (1913). The seedlings of the angophoras with description of a new species. J. \& Proc. Roy. Soc. New South Wales 47: 98-105.

Hillis, W. E. (1967). Polyphenols in the leaves of Eucalyptus : a chemotaxonomic survey. V. The series Cornutae and Subcornutae of the section Macrantherae and the section Platyantherae. Phytochem. 6: $845-856$.

Ingle, H. D. \& Dadswell, H. E. (1953). The anatomy of the timbers of the South-West Pacific area. III. Myrtaceae. Austral. J. Bot. 1: 353-400.

Jacobs, M. R. (1955). 'Growth Habits of the Eucalypts' (Forestry and Timber Bureau: Canberra).

Johnson, L. A. S. (1972). Evolution and classification in Eucalyptus. Proc. Linn. Soc. New South Wales 97: 11-29.

Johnson, L. A. S. (1976). Problems of species and genera in Eucalyptus (Myrtaceae). Plant Syst. Evol. 125: 155-167.

Johnson, L. A. S. (1984). The genera of the eucalypts. Austral. Syst. Bot. Soc. Newsletter 39: 25-28.

Ladiges, P. Y. (1984). A comparative study of trichomes in Angophora Cav. and Eucalyptus L'Hérit. - a question of homology. Austral. J. Bot. 32: 561-574. 
Ladiges, P. Y. \& Humphries, C. J. (1983). A cladistic study of Arillastrum, Angophora and Eucalyptus (Myrtaceae). Bot. J. Linn. Soc. 87: 105-134.

Lange, R. T. (1978). Carpological evidence for fossil Eucalyptus and other Leptospermae (subfamily Leptospermoideae of Myrtaceae) from a tertiary deposit in the South Australian arid zone. Austral. J. Bot. 26: 221-233.

Leach, G. J. (1980). 'A Systematic and Evolutionary Study of the Genus Angophora (Myrtaceae)'. Ph.D. thesis. La Trobe University, Melbourne.

Leichhardt, L. (1847). 'Journal of an Overland Expedition from Moreton Bay to Port Essington, 1844-1845' (T. \& W. Boone: London).

McGrath, J. (1974). 'The Ecological Distribution of Angophora and its Hybrids in the Sydney Region'. Honours thesis. University of Sydney, Sydney.

McVaugh, R. (1956). Nomenclatural notes on Myrtaceae and related families. Taxon 5: 133-147.

Pederick, L. A. \& Lennox, F. G. (1979). Variation in polyphenolic constituents of Eucalyptus nitens Maiden. Austral. J. Bot. 27: 217-226.

Penfold, A. R. \& Willis, J. L. (1961). 'The Eucalypts. Botany, Cultivation, Chemistry and Utilization.' World Crops Series. (Leonard Hill: London).

Persoon, C. H. (1806). 'Synopsis Plantarum' (Paris) vol. 2, pp. 25-26.

Pike, L. M. (1956). Pollen morphology of Myrtaceae from the South-West Pacific area. Austral. J. Bot. 4: 13-53.

Prakash, N. (1969). A contribution to the life history of Angophora floribunda (Sm.) Sweet (Myrtaceae). Austral. J. Bot. 17: 457-469.

Pryor, L. D. \& Johnson, L. A. S. (1971). 'A Classification of the Eucalypts' (Australian National University: Canberra).

Pryor, L. D. \& Knox, R. B. (1971). Operculum development and evolution in eucalypts. Austral. J. Bot. 19: 143-171.

Smith, H. G. (1913). On the essential oils of the angophoras. J. \& Proc. Roy. Soc. New South Wales 47: 106-119.

Smith, J. E. (1797). Dr Smith's botanical characters of some plants. Trans. Linn. Soc. London 3: 266-268.

Smith, J. E. (1805). Metrosideros hispida. Exotic Botany 1: 81-82.

Smith-White, S. (1942). Cytological studies in the Myrtaceae. I. Microsporogenesis in several genera of the tribe Leptospermoideae. Proc. Linn. Soc. New South Wales 67: 335-342.

Ventenat, E. P. (1803). 'Jardin de la Malmaison' (Paris) vol.1, t. 5. 